Boletín de la Sociedad Geológica Mexicana

VOLUMEN 61, NÚM. 1, 2009, P. 31-45

\title{
Bioaccumulation of some trace elements in the biota of hydrothermal fields of the Guaymas Basin (Gulf of California)
}

\author{
Ludmila L. Demina ${ }^{1, *}$, Sergey V. Galkin ${ }^{1}$ and Evgueni N. Shumilin ${ }^{2}$ \\ ${ }^{1}$ P.P.Shirshov Institute of Oceanology, Russian Academy of Sciences, Moscow, Russia \\ ${ }^{2}$ Centro Interdisciplinario de Ciencias Marinas, Avenida IPN s/n, Col. Playa Palo de Santa Rita, Apartado Postal 592, La Paz, Baja \\ California Sur, 23096, Mexico \\ *1demina@ocean.ru
}

\begin{abstract}
Data from the hydrothermally influenced Guaymas Basin of the Gulf of California are presented on the concentration and distribution of $\mathrm{Ag}, \mathrm{As}, \mathrm{Au}, \mathrm{Ba}, \mathrm{Cd}, \mathrm{Co}, \mathrm{Cr}, \mathrm{Cu}, \mathrm{Fe}, \mathrm{Hg}, \mathrm{Mn}, \mathrm{Pb}, \mathrm{Sb}, \mathrm{Se}$, and $\mathrm{Zn}$ in different tissues of dominant hydrothermal vent animals such as vestimentifera Riftia pachyptila and vesicomyid clams Archivesica gigas and other organisms, including Spongia, bivalve mollusks Nuculana grasslei, Phelliactis pabista, and crab Munidopsis alvisca. Chemical element content was measured by atomic absorption spectrometry (flame and graphite furnace methods) and instrumental neutron activation analysis.

In the dominant specialized taxa, the main target organs of metals were the trophosome and obturaculae of Riftia pachyptila, the gills and mantle of Archivesica gigas. The other organisms also demonstrated high bioaccumulation of metals. Especially high levels of most of the metals (excluding Mn) were detected in the soft body of Nuculana grasslei. The highest Mn content was found in the whole body of Spongia. Bioconcentration factor of the trace metals studied varies within three orders of magnitude from $5(\mathrm{Mn})$ to $3 \cdot 10^{4}(\mathrm{Cd})$. This testifies apparently a selectivity of trace metal bioaccumulation by the organisms which is determined by metal bioavailability independently of metal concentration in the water column. Variability in the molar ratio Fe/Mn allows us to assume that these metals undergo fractionation during migration from the hydrothermal fluids to the interior organs of animals. Insignificant differences between the $\mathrm{Cd}, \mathrm{Cu}, \mathrm{Fe}, \mathrm{Hg}, \mathrm{Pb}$, and $\mathrm{Zn}$ levels in the Guaymas Basin vent clams versus that in the bivalve mollusks from polluted areas of the Gulf of California might suggest that the metal bioavailability play an important role in the bioaccumulation.
\end{abstract}

Key words: trace metals; bioaccumulation; Guaymas Basin; hydrothermal communities.

\section{Resumen}

Se presentan los datos sobre la concentración y distribución de $\mathrm{Ag}, \mathrm{As}, \mathrm{Au}, \mathrm{Ba}, \mathrm{Cd}, \mathrm{Co}, \mathrm{Cr}, \mathrm{Cu}, \mathrm{Fe}, \mathrm{Hg}, \mathrm{Mn}, \mathrm{Pb}, \mathrm{Sb}, \mathrm{Se}$, and $\mathrm{Zn}$ en diferentes tejidos de los animales predominantes en las ventilas hidrotermales tales como la vestimentifera Riftia pachyptila, la almeja

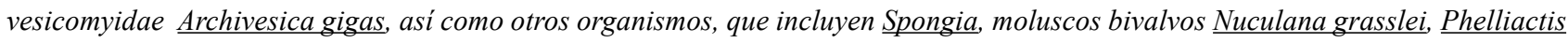
pabista, y el cangrejo Munidopsis alvisca. El contenido de los elementos químicos fue medido por medio de espectrofotometría de absorción atómica (métodos de flama y de horno de grafito) y por el análisis instrumental de la activación neutrónica.

En la taxa especializada dominante, los órganos principales en los cuales se acumularon los metales fueron el trofosoma y el obturaculae de Riftia pachyptila, las branquias y el manto de Archivesica gigas. Los otros organismos también mostraron alta bioacumulación de metales. Especialmente altos niveles de la mayoría de los metales (excepto Mn) fueron detectados en el cuerpo suave de Nuculana grassley. El contenido más alto de Mn fue encontrado en todo el cuerpo de Spongia. El factor de bioconcentración para los metales traza estudiados varía en tres ordenes de magnitud desde $5(\mathrm{Mn})$ a $3 \bullet 10^{4}(\mathrm{Cd})$. Esto aparentemente evidencia cierta selectividad en la bioacumulación de los metales traza por los organismos, la cual es determinada por la biodisponibilidad independientemente de la concentración de metales en la columna del agua. La variabilidad de la razón molar de Fe/Mn nos permite asumir que estos 
metales durante la migración desde los fluidos hidrotermales hacia los órganos internos de animales están sujetos a fraccionación. Las diferencias insignificantes entre los niveles de $\mathrm{Cd}, \mathrm{Cu}, \mathrm{Fe}, \mathrm{Hg}, \mathrm{Pb}$ y $\mathrm{Zn}$ en las almejas de las ventilas de la Cuenca de Guaymas y los niveles de los moluscos bivalvos de áreas contaminadas del Golfo California podrian sugerir que la biodisponibilidad de los metales juega un papel importante en la bioacumulación.

Palabras clave: metales pesados; bioacumulación; Cuenca Guaymas; comunidades hidrotermales.

\section{Introduction}

Deep-sea hydrothermal vent fields are inhabited by many thermophilic organisms that are able to survive under extreme physical and chemical conditions, including high loads of trace metals and redox gases (Anonymous, 1995; Sarradin et al., 2008; Van Dover, 2000). An exceptional feature of the semi-enclosed Guaymas Basin (Gulf of California) hydrothermal vent field is the thick organic-rich sedimentary cover on the seafloor. This cover is a result of high sedimentation rates due to Colorado River sediment input directly before dam construction or tidal resuspension of previously supplied terrigenous sediments in the Upper Gulf of California (Calvert, 1966; Carriquiry and Sánchez, 1999; Carriquiry et al., 2001) and biogenic particles from the highly productive euphotic zone (Lonsdale et al., 1980; De la Lanza-Espino and Soto, 1999; Thunell, 1998). High-temperature fluids are discharged to the surrounding seawater through the vents and by ascending through the overlying sediments, which are rich in Mn. This leads to the enrichment of fluids for Mn relative to Fe (Von Damm et al., 1985), which is a characteristic feature of Guaymas Basin fluids compared to other vent fields. From this standpoint, it is interesting to examine the trace metal and other element contents of the hydrothermal organisms inhabiting the vent environments, especially since the relationships between organisms from the Guaymas Basin and metals have not been thoroughly studied thus far. There are few articles devoted to the chemical composition of Guaymas Basin organisms, and those that do exist focus on heavy metals in dominant taxa inhabiting vent environment, such as vestimentifera Riftia (Lein et al., 1989; Lukashin et al., 1990; Ruelas-Inzunza et al., 2005), bivalve mollusks Archivesica gigas (Lein et al., 1989; Lukashin et al., 1990) and Vesicomya gigas (Ruelas-Inzunza et al., 2003). Meanwhile, little is known about metal bioaccumulation in other taxa that live in the vent areas and their periphery but are not dependent upon symbiotrophy. The dominant hydrothermal fauna studied here is represented by the highly specialized taxa vestimentifera Riftia pachyptila and clam Vesicomyidae Archivesica gigas, both of which are nutritionally dependent on the chemosynthetic bacterial community. We also consider other organisms such as Spongia, bivalve mollusk Nuculana grasslei, Phelliactis pabista, and crab Munidopsis alvisca.

The aim of this work was to study features of the distribution of 15 chemical elements (including Ag, As, $\mathrm{Sb}$ and $\mathrm{Au}$, as well as organic carbon or $\mathrm{C}_{\mathrm{org}}$, for which there were no published data on these organisms) in the fauna microhabitats, the tissues and whole bodies of the hydrothermal organisms from the Guaymas Basin, including the dominant specialized symbiotrophic and the peripheric taxa. Besides, it is interesting to estimate the concentration factors of metals in organisms relative to the water column. There are a some mining complexes located in the Baja California peninsula, as well as other different types of industrial and urban activities along the coastal zone of the Gulf of California, which sometimes could produce a deficiency of oxygen, acidic conditions and high discharges of heavy metals into the ecosystems. We aim to determine whether there are any differences in the heavy metal content of the organisms exposed to hydrothermal and anthropogenic impacts.

\section{Materials and methods}

\subsection{Geological setting and faunal distribution}

The Southern trough of the Guaymas Basin's hydrothermal field is located at $2020 \mathrm{~m}$ depth $\left(27^{\circ} 00.70^{\prime} \mathrm{N}\right.$, $\left.111^{\circ} 24.40^{\prime} \mathrm{W}\right)$, presented in Figure 1. The intense tectonic activity in this area is caused by the displacement of the Baja California peninsula towards the NW at a spreading rate of about $6 \mathrm{~cm}$ per year (Klitgord et al., 1974; Lonsdale et al., 1980). An exceptional feature of the semi-enclosed Guaymas Basin's hydrothermal vent field is the thick organic-rich sedimentary cover of the seafloor. This is a result of high sedimentation rates (1-2 $\mathrm{mm}$ per year) due to significant terrigenous input from the Colorado River (Calvert, 1966) before its complete damming in 1956, tidal resuspension of sediments from the Colorado River delta in the Upper Gulf of California, and the high productivity of the euphotic zone of the Gulf of California (De la Lanza-Espino and Soto, 1999; Thunell, 1998). The surface sediments of the Guaymas Basin also have a Mn-oxide-rich and (relatively) Fe-oxide-rich turbidite layer that affects the distribution of $\mathrm{C}, \mathrm{Fe}, \mathrm{Mn}, \mathrm{S}$ and some trace metals (Otero et al., 2003). Iron is mainly pyritized in the sediments, while $\mathrm{Mn}$ is found predominantly in carbonates $(41 \pm 12$ $\%)$ and is associated with pyrite to a much lesser degree; $\mathrm{Co}, \mathrm{Cr}, \mathrm{Cu}, \mathrm{Ni}$ and $\mathrm{Zn}$ were highly pyritized $(>80 \%$ ) in 


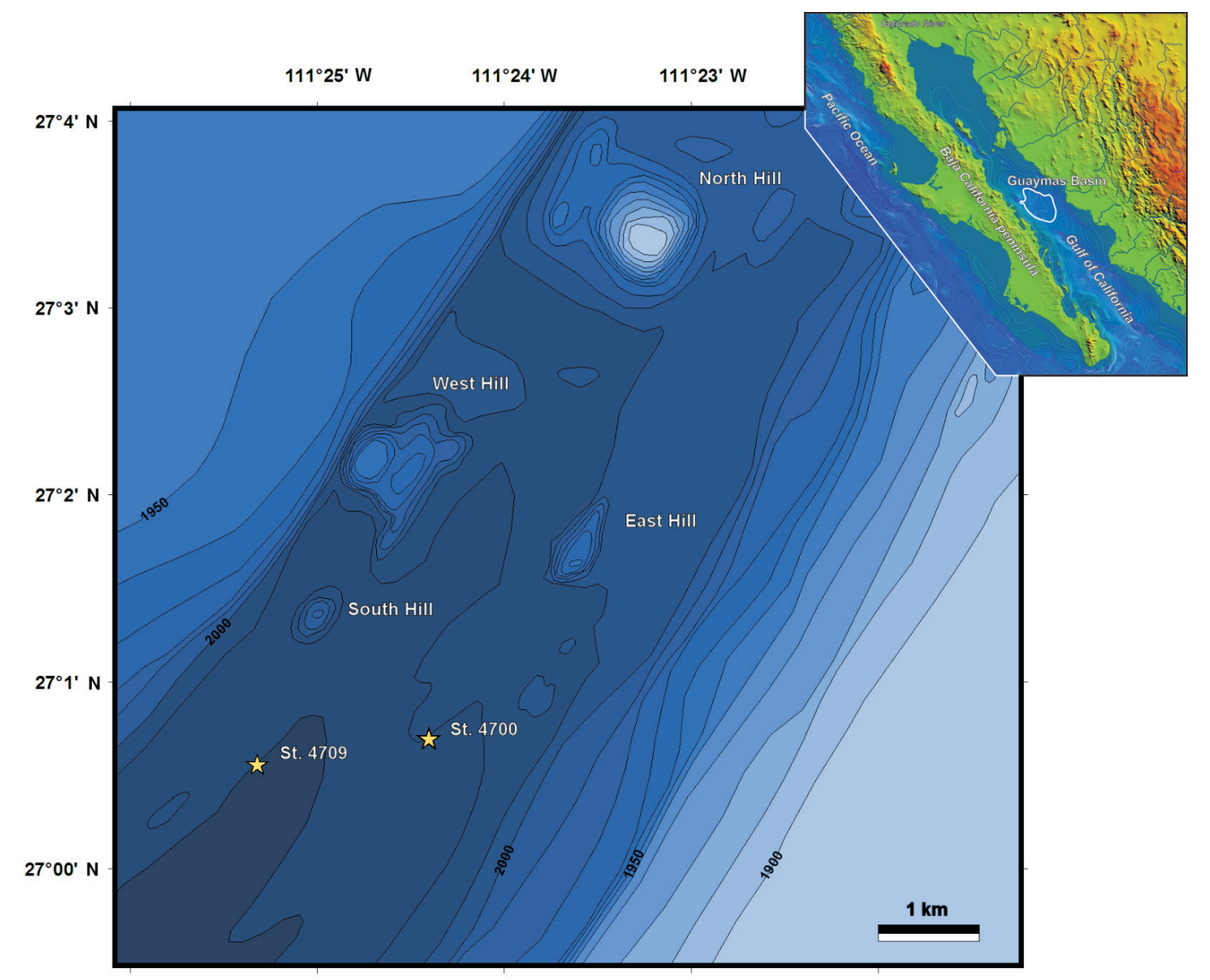

Figure 1. Study area and location of sampling sites in the Guaymas Basin's hydrothermal field of the Gulf of California

the sediments of the Guaymas Basin (Otero et al., 2003). The low-temperature hydrothermal mineral associations on the floor of the Guaymas Basin are represented by opal and barite, while pyrrhotite, sphalerite and chalcopyrite are the dominant ore minerals in high-temperature areas (Bogdanov et al., 2004). It is interesting to note that both mineral formations contain oil hydrocarbons, with a content of $\mathrm{C}_{\text {org }}$ in the surface sediments ranging from $0.15 \%$ (high-temperature area) to $2.23 \%$ (low-temperature area) (Bogdanov et al., 2004) and reaching up to $6.21 \%$ in some deposits saturated with hydrocarbons (Peresypkin, personal communication). More than a hundred high-temperature hydrothermal mounds (black smokers) in an area of $30 \mathrm{~km}^{2}$ were discovered and described by Lonsdale et al. (1980). Sulfide chimneys commonly grow through overlying sediments and can reach heights of more than $25 \mathrm{~m}$. Hightemperature fluids (maximum temperatures of up to $315^{\circ} \mathrm{C}$ ) are emitted from the vents into the surrounding water. Warm fluids flow through the chimney walls and ascend past the sedimentary cover, which is enriched with organic matter. This leads to a complicated transformation of organic matter into hydrocarbons and methane (Von Damm et al., 1985) that is characteristic of the Guaymas Basin fluids compared to other known vent fields.
Of the variety of factors determining fauna distribution, temperature and substratum characteristics are the easiest to estimate during bottom observation. Precise data is lacking in most cases, but numerous visual observations accompanied by temperature estimations have found that black smokers have a temperature in the range 275$400^{\circ} \mathrm{C}$, while white smoker temperature varies from 100 to $250^{\circ} \mathrm{C}$ (BRIDGE Workshop Report, 1994). The heat extreme for most vent zone inhabitants seems to be about $25-40^{\circ} \mathrm{C}$. A few prominent zones can be identified in the Guaymas Basin's hydrothermal vent field, each of which is dominated by certain megafaunal groups: 1) the euthermal or shimmering water zone (ambient temperature of about $25-30^{\circ} \mathrm{C}$ ), where vestimentiferans commonly live; 2 ) the oligothermal zone (temperatures of 3-6 to $25^{\circ} \mathrm{C}$ ), which is populated by vesicomyid clams and mytilid mussels; 3 ) the periphery of the vent zone (near-field, with very low or absent temperature anomalies), where specialized suspension-feeders consuming bacteria are the predominant taxa; and 4) the periphery of the vent zone (far-field, without temperature anomalies), which is occupied by non-vent suspension-feeders (Galkin, 2002).

Abundant settlements of vestimentifera Riftia pachyptila, reaching up to $1 \mathrm{~m}$ length and occupying areas of up to 
hundreds $\mathrm{m}^{2}$, were detected in the shimmering water at the hydrothermal chimney surfaces. The basic group of fauna inhabiting the soft sedimentary cover is the vesicomyid clam Archivesica gigas whose settlements can accumulate up to hundreds specimens per $\mathrm{m}^{2}$. These communities of organisms are nutritionally dependent on the chemosynthetic bacterial community and are typically surrounded by accumulations of the bivalve mollusks Nuculana grasslei (Allen, 1993). Sediments soaked with hydrocarbons serve as a substratum for these organisms. Chimney walls and bases are inhabited by Munidopsis alvisca crabs (predator), Spongia (filter-feeder) and Phelliactis pabista (filter-feeder and predator). The latter were often attached to the shells of the vesicomyid clam Archivesica gigas. Thick bacterial mats (with a thickness of up to a few $\mathrm{cm}$ ) cover significant areas (hundreds of $\mathrm{m}^{2}$ ).

\subsection{Fluid and animal collection}

The material studied involved water samples taken from the habitat of the vestimentifera Riftia (two shimmering water samples from St. 4700 , at $27^{\circ} 00^{\prime} 48 \mathrm{~N}, 111^{\circ} 24^{\prime} 74 \mathrm{~W}$ ) as well as from the habitat of the vesicomyid clam Archivesica gigas (two water samples from the low temperature diffuser habitats St.4709 (2600’34 N, 111 '24'78 W). Twenty-five samples of different organs and tissues from the dominant bottom organisms were also collected in the Guaymas Basin vent field (Figure 1). These samples were taken during the 49th cruise of the Russian research vessel "Akademik Mstislav Keldysh" (16-20 October, 2003) using the "Mir1 " and "Mir-2" manned submersibles. Water samples were collected by the "Mir" submersibles using $700 \mathrm{ml}$ titanium syringes designed for sampling of hot fluids. Aboard the ship, the samples were immediately filtered trough a $1 \mu \mathrm{m}$ pore size nucleopore filter and placed afterwards into acidwashed high density polyethylene bottles and acidified to pH 2 with nitric acid (super pure MERCK). Water samples were stored in the refrigerator until analysis in the stationary laboratory, which determined the content of total dissolved chemical elements.

The samples of bottom fauna were collected using the "slurp-gun" and sieve nets operated by the submersibles. Each sample was washed with deionized water aboard the ship to eliminate sea salts and then measured and freshly dissected into the main organs; some individuals were taken as a whole body. The shells of mollusks and the vestimentiferan tubes were rinsed with deionized water after being separated from the interior organs, but they were not treated with a $10 \%$ solution of $\mathrm{HNO}_{3}$ (as was done by Kádár and Costa, 2006), as this could have eliminated bacterial overgrowth and extracted the adsorbed fraction of metals from the surfaces of these organs. This method of shell preparation allowed us to study the total amount of metals in the external organs of invertebrates, whether incorporated into the shell or adsorbed onto their surface. The samples were dried at $60^{\circ} \mathrm{C}$ and stored in insulated plastic bags until analysis.

\subsection{Pretreatment and chemical analysis of samples}

The animal samples (ranging from 10 to $50 \mathrm{mg}$ in weight) were carefully powdered and digested with a $1 \mathrm{ml}$ mixture (2:1) of ultra pure Merck concentrated nitric acid $(69 \% \mathrm{v} / \mathrm{v})$ and $30 \%$ hydrogen peroxide in Teflon vessels with MWS-2 microwave system (Berghof, Germany). Before analytical measurement, the water samples of fluids and the obtained solutions of digested tissues were diluted to $1: 5$ and $1: 10$, respectively, using high purity deionized water. The concentrations of the chemical elements in fluids were determined by atomic absorption spectrophotometry using a KVANT-2A instrument (flame version) and a KVANT-ZETA instrument (graphite furnace version) at the P.P. Shirshov Institute of Oceanology (Moscow, Russia) of the Russian Academy of Sciences. Some elements were determined by instrumental neutron activation analysis at the V.I. Vernadsky Institute of Geochemistry and Analytical Chemistry (Moscow, Russia) of the Russian Academy of Sciences. The details of the analytical methods employed are given in Table 1. The detection limits for flameless AAS measurements were $0.5 \mu \mathrm{g} \mathrm{l}^{-1}$ (Ag), $0.7 \mu \mathrm{g} \mathrm{l}^{-1}$ (As), 0.1 $\mu \mathrm{g} \mathrm{l}^{-1}(\mathrm{Cd}$ and $\mathrm{Cu}), 0.2 \mu \mathrm{g} \mathrm{l}^{-1}$ (Co and $\left.\mathrm{Cr}\right), 0.1 \mu \mathrm{g} \mathrm{l}^{-1}$ (Fe), $0.2 \mu \mathrm{g} \mathrm{l}^{-1}(\mathrm{Mn}), 1 \mu \mathrm{g} \mathrm{l}^{-1}$ (Sb and Se) and $0.05 \mu \mathrm{g} \mathrm{l}^{-1}(\mathrm{Zn})$. Standard solutions for metal determination were prepared using certified State Standard Samples (GSO). Accuracy of the analysis was controlled through the use of international reference materials: NIST SRM 2976 (mussel tissue), IAEA MA-A-2/T (fish flash) and GSD-7. A comparison of the metal concentrations of certified standard reference materials with the measured values revealed a percentage recovery rate of between $92-95 \%$ for $\mathrm{Cu}, \mathrm{Fe}, \mathrm{Mn}$ and $\mathrm{Zn}$; 86-90\% for $\mathrm{Ag}, \mathrm{Cd}, \mathrm{Co}, \mathrm{Cr}$ and $\mathrm{Pb} ; 82-85 \%$ for $\mathrm{Hg}, \mathrm{Sb}$, and Se. Determination of organic carbon was carried out in 14 samples using a Carbon Express-Analyzer AN-2975 M; with an accuracy of $0.1 \%$.

Tabla 1. Analytical techniques and precision of the methods

\begin{tabular}{|c|c|c|}
\hline Elements, object & Analytical technique & $\begin{array}{l}\text { Precision } \\
\%\end{array}$ \\
\hline $\begin{array}{l}\mathrm{Cu}, \mathrm{Fe}, \mathrm{Mg} \text { and } \mathrm{Zn} \text { in } \\
\text { fluids }\end{array}$ & $\begin{array}{l}\text { Flame Atomic Absorption Spec- } \\
\text { trophotometry (AAS) }\end{array}$ & 5 \\
\hline $\begin{array}{l}\mathrm{Ag}, \mathrm{As}, \mathrm{Cd}, \mathrm{Co}, \mathrm{Cr}, \mathrm{Pb}, \\
\text { and } \mathrm{Sb} \text { in fluids }\end{array}$ & Graphite furnace AAS & 12 \\
\hline $\begin{array}{l}\mathrm{As}, \mathrm{Au}, \mathrm{Ba}, \mathrm{Co}, \mathrm{Cr}, \mathrm{Fe} \\
\mathrm{Sb}, \mathrm{Se} \text { in organisms }\end{array}$ & $\begin{array}{l}\text { Instrumental neutron activation } \\
\text { analysis }\end{array}$ & 15 \\
\hline $\begin{array}{l}\mathrm{Cu}, \mathrm{Mn} \text { and } \mathrm{Zn} \text { in } \\
\text { organisms }\end{array}$ & $\begin{array}{l}\text { Flame Atomic Absorption Spec- } \\
\text { trophotometry (AAS) }\end{array}$ & 8 \\
\hline $\begin{array}{l}\mathrm{Ag}, \mathrm{Cd} \text {, and } \mathrm{Pb} \text { in } \\
\text { organisms }\end{array}$ & Graphite furnace AAS & 10 \\
\hline $\mathrm{Hg}$ & $\begin{array}{l}\text { Cold vapor concentration - Graph- } \\
\text { ite furnace AAS after reduction } \\
\text { with } \mathrm{SnCl}_{2}\end{array}$ & 14 \\
\hline
\end{tabular}




\subsection{Data treatment}

Standard statistical software was used for the data treatment. The bioconcentration factor $\left(\mathrm{F}_{\mathrm{c}}\right)$ was also calculated accordingly to a relation:

$$
\mathrm{F}_{\mathrm{c}}=\mathrm{C}_{\mathrm{m}} / \mathrm{C}_{\text {water }}
$$

where $\mathrm{C}_{\mathrm{m}}$ - metal content in the whole organism (mg $\mathrm{kg}^{-1}$ dry weight), calculated from the concentrations of each metal in organs, constitutioning whole body of the animal, on the base of the percentage of mass of each organ, and $\mathrm{C}_{\text {water }}$ is the concentration of metal in corresponding hydrothermal solution ( $\mathrm{mg} \mathrm{kg}^{-1}$ ).

\section{Results}

\subsection{Heavy metals in the fauna microhabitats}

The results of element determination for the four fluid samples are listed in Table 2. Samples collected from shimmering water ("hot fluids" of the first type) at St. 4700 had a weakly acidic character $(\mathrm{pH}=5.4)$, while samples collected from a nearby diffuser vent ("warm fluids" of the second type) at St.4709 were more alkaline ( $\mathrm{pH}=7.49)$. In both cases, $\mathrm{pH}$ is rather low in comparison to ocean water (usually pH 8.0-8.2; Millero, 1996). Fluids of the first type are more deficient in $\mathrm{Mg}$ than fluids of the second type. The $\mathrm{Mg}$ concentrations of both types of fluids are somewhat lower than observed in ocean water. In both cases, the trace metal contents are much higher in the fluid samples relative to the reference ocean water. According to our data, fluids of the first type are enriched in $\mathrm{As}, \mathrm{Cr}, \mathrm{Cu}, \mathrm{Fe}, \mathrm{Mn}$, and $\mathrm{Pb}$ relative to fluids of the second type, but deficient in $\mathrm{Ag}, \mathrm{Cd}$, $\mathrm{Sb}$ and $\mathrm{Zn}$. The $\mathrm{Mn}$ and $\mathrm{Zn}$ concentrations show the largest difference between the two types of fluids (Table 2).

\subsection{Trace metals in the Guaymas Basin organisms}

Average values for metal content ( $\mathrm{mg} \mathrm{kg}^{-1}$ dry weight) in the different tissues of organisms and, in some cases, the whole bodies, are presented in Table 3 . The highest metal contents over all the samples studied were found for nutritionally important $\mathrm{Ba}, \mathrm{Fe}, \mathrm{Mn}$ and $\mathrm{Zn}$ (with peak concentrations of up to thousands of $\mathrm{mg} \mathrm{kg}^{-1}$ ), followed by $\mathrm{Cu}$ (up to hundreds of $\mathrm{mg} \mathrm{kg}^{-1}$ ) and $\mathrm{Ag}, \mathrm{As}, \mathrm{Cr}, \mathrm{Pb}$ and $\mathrm{Sb}$ (up to dozens of $\mathrm{mg} \mathrm{kg}^{-1}$ ). Contents of $\mathrm{Cd}, \mathrm{Co}, \mathrm{Hg}$ and $\mathrm{Se}$ did not exceed $5 \mathrm{mg} \mathrm{kg}^{-1}$, while Au had the lowest content, typically less than $0.1 \mathrm{mg} \mathrm{kg}^{-1}$. The differences in the maximal and minimal contents of the pooled metals reached up to six orders of magnitude.

Vestimentifera Riftia is a highly specialized symbiotrophic and the most abundant organism the East Pacific Rise. It inhabits shimmering waters and is nutritionally dependent on the reduced substances (mainly $\mathrm{H}_{2} \mathrm{~S}$ ) contained in the hydrothermal fluids. Chemical analysis of separate organs of mature individuals (which have a tube length of up to $51 \mathrm{~cm}$ ) have revealed two groups of elements that can be distinguished based on their contents: i) As, $\mathrm{Ba}, \mathrm{Cu}$, $\mathrm{Fe}, \mathrm{Mn}$ and $\mathrm{Zn}$ with average contents between 10 and $450 \mathrm{mg} \mathrm{kg}^{-1}$ (Figure 2a); ii) $\mathrm{Ag}, \mathrm{Cd}, \mathrm{Co}, \mathrm{Cr}, \mathrm{Hg}, \mathrm{Pb}, \mathrm{Sb}$, and $\mathrm{Se}$ with average contents below $10 \mathrm{mg} \mathrm{kg}^{-1}$ (Figure 2b). Different organs of Riftia show various capacities for accumulating metals. The differences are obviously associated with distinctions in their functions. $\mathrm{Ag}, \mathrm{Co}, \mathrm{Fe}$ and $\mathrm{Hg}$ are accumulated to a greater extent in trophosomes relative to the other organs. The highest $\mathrm{Ba}$ concentration was found in Riftia's tube, which consists primarily of chitin and is covered with a thick layer of bacterial biomass. The highest As, Cd, Mn, Se and $\mathrm{Zn}$ contents were found in the obturaculae, which is the anterior lociniate (or wing) end directed toward fluids. The opisthosome is the posterior end and is attached to the substratum. Relative to other Riftia's organs it is noticeably enriched in $\mathrm{Co}, \mathrm{Cu}$ and $\mathrm{Sb}$. The vestimentum, which represents the middle muscular, collar-like part of the body, is enriched in $\mathrm{Pb}$ relative to other organs. Gonads, which are responsible for reproduction, accumulate more $\mathrm{Cr}$ than other organs (Figure $2 \mathrm{~b}$ ). The highest organic carbon $\left(\mathrm{C}_{\text {org }}\right)$ content $(28.53 \%)$ was detected in the trophosome. This occurs quite naturally due to accumulation of endosymbiotic bacteria. Meanwhile, the lowest $\mathrm{C}_{\text {org }}$ value $(20.32 \%)$ was found in the vestimentifera tube.

The second dominant specialized taxon is the vesicomyid clam Archivesica gigas, whose gills are the main target organ of $\mathrm{Zn}\left(3110 \mathrm{mg} \mathrm{kg}^{-1}\right)$ and $\mathrm{Cu}\left(42.5 \mathrm{mg} \mathrm{kg}^{-1}\right)$, along with very similar value of $45.54 \mathrm{mg} \mathrm{kg}^{-1}$ in mantle, $\mathrm{Cr}$ (21.4 $\left.\mathrm{mg} \mathrm{kg}^{-1}\right)$, Co $\left(1.3 \mathrm{mg} \mathrm{kg}^{-1}\right)$, and Se (1.5 $\left.\mathrm{mg} \mathrm{kg}^{-1}\right)$. The content of these metals in gills is much higher (up to one

Table 2. Concentrations of elements in the water samples from the Guaymas Basin's hydrothermal field (average \pm standard deviation)

\begin{tabular}{lcccccccccccc}
\hline \multicolumn{1}{|c}{ Water sample type } & $\begin{array}{c}\mathrm{Ag}, \\
\mathrm{nM}\end{array}$ & $\begin{array}{c}\mathrm{As}, \\
\mathrm{nM}\end{array}$ & $\begin{array}{c}\mathrm{Cd}, \\
\mathrm{nM}\end{array}$ & $\begin{array}{c}\mathrm{Co}, \\
\mathrm{nM}\end{array}$ & $\begin{array}{c}\mathrm{Cr}, \\
\mathrm{nM}\end{array}$ & $\begin{array}{c}\mathrm{Cu}, \\
\mu \mathrm{M}\end{array}$ & $\begin{array}{c}\mathrm{Fe}, \\
\mu \mathrm{M}\end{array}$ & $\begin{array}{c}\mathrm{Mg}, \\
\mathrm{mM}\end{array}$ & $\begin{array}{c}\mathrm{Mn}, \\
\mu \mathrm{M}\end{array}$ & $\begin{array}{c}\mathrm{Pb}, \\
\mathrm{nM}\end{array}$ & $\begin{array}{c}\mathrm{Sb}, \\
\mathrm{nM}\end{array}$ & $\begin{array}{c}\mathrm{Zn}, \\
\mu \mathrm{M}\end{array}$ \\
\hline $\begin{array}{l}\text { First type (n=2): hot, } \\
\text { pH 5.40 }\end{array}$ & $2 \pm 1$ & $700 \pm 80$ & $2 \pm 1$ & $190 \pm 130$ & $760 \pm 230$ & $0.66 \pm 0.16$ & $20.6 \pm 2.5$ & $34.00 \pm 1.2$ & $43.6 \pm 3.6$ & $41 \pm 5$ & $30 \pm 11$ & $0.32 \pm 0.11$ \\
$\begin{array}{l}\text { Second type (n=2): } \\
\text { warm, pH 7.49 }\end{array}$ & $26 \pm 8$ & $100 \pm 50$ & $4 \pm 1$ & $160 \pm 110$ & $470 \pm 120$ & $0.29 \pm 0.07$ & $7.5 \pm 1.4$ & $43.10 \pm 2.32$ & $1.48 \pm 0.06$ & $16 \pm 9$ & $50 \pm 13$ & $18.75 \pm 1.24$ \\
Ocean water (Li, 1991) & 0.02 & 22 & 0.7 & 0.03 & 5 & 0.003 & 0.004 & 52.2 & 0.001 & 0.01 & 1.2 & 0.011 \\
\hline
\end{tabular}


Table 3. Content ( $\mathrm{mg} \mathrm{kg}^{-1}$ dry weight) of some elements in organism tissues and whole organisms inhabited the Southern trough of the Guyamas Basin

\begin{tabular}{|c|c|c|c|c|c|c|c|c|c|c|}
\hline $\begin{array}{l}\text { Taxon (number of } \\
\text { specimens) }\end{array}$ & Tissue & $\mathrm{Ag}$ & As & $\mathrm{Au}$ & & $\mathrm{Ba}$ & $\mathrm{Cd}$ & Co & $\mathrm{Cr}$ & $\mathrm{Cu}$ \\
\hline \multirow{5}{*}{$\begin{array}{l}\text { Riftia pachyptila }(\mathrm{n}=3), \\
\text { tube length }=10-21.5 \mathrm{~cm}\end{array}$} & trophosome & $3.46 \pm 1.2$ & $7.12 \pm 1.5$ & \multicolumn{2}{|c|}{$0.018 \pm 0.004$} & $34 \pm 3$ & $1.86 \pm 0.32 \quad 3.2$ & $3.24 \pm 1.53$ & $1.1 \pm 0.4$ & $15.4 \pm 2.6$ \\
\hline & obturaculae & $0.62 \pm 0.23$ & $6.3 \pm 1.8$ & $0.019 \pm 0.005$ & $.005 \quad 137$ & $375 \pm 220$ & $12.1 \pm 1.7 \quad 0.3$ & $0.35 \pm 0.27 \quad 0$. & $0.69 \pm 0.2$ & $7.9 \pm 2.7$ \\
\hline & opisthosome & $1.25 \pm 0.15$ & $0.73 \pm 0.1$ & \multicolumn{2}{|c|}{$0.023 \pm 0.007$} & $56 \pm 5$ & $2.44 \pm 0.32 \quad 0$. & $0.97 \pm 0.73 \quad 2.8$ & $2.87 \pm 1.45$ & $0.6 \pm 0.2$ \\
\hline & vestimentum & $0.43 \pm 0.12$ & $3.67 \pm 0.95$ & $0.03 \pm 0.01$ & .01 & $290 \pm 45$ & $2.0 \pm 0.4$ & $0.32 \pm 0.15 \quad 1$. & $.47 \pm 0.43$ & $7.9 \pm 3.2$ \\
\hline & tube & nd & $3.59 \pm 1.0$ & \multicolumn{2}{|c|}{$0.019 \pm 0.007$} & $335 \pm 38$ & $1.04 \pm 0.42$ & $1.78 \pm 0.64 \quad 5$. & $.44 \pm 1.38$ & $11.3 \pm 3.5$ \\
\hline \multirow{6}{*}{$\begin{array}{l}\text { Riftia pachyptila }(\mathrm{n}=1) \\
\text { tube length }=51 \mathrm{~cm}\end{array}$} & trophosome & 0.92 & 17.8 & 0.007 & & 7 & 0.44 & 0.34 & 3.14 & 34.0 \\
\hline & obturaculae & 0.74 & 46.4 & 0.025 & & 42 & 2.02 & 0.28 & 2.6 & 24.3 \\
\hline & opisthosome & 0.62 & 10.1 & nd & & 38 & 0.60 & 2.95 & 0.46 & 42.8 \\
\hline & vestimentum & 0.4 & 2.25 & 0.014 & & 45 & 0.08 & 0.37 & 0.41 & 8.7 \\
\hline & gonades & 0.48 & 0.34 & 0.007 & & 115 & 0.07 & 1.28 & 3.76 & 4.6 \\
\hline & tube & nd & 1.93 & nd & & 200 & 0.38 & 0.48 & 4.78 & 26.3 \\
\hline \multirow{3}{*}{$\begin{array}{l}\text { Riftia pachyptila }(\mathrm{n}=1), \\
\text { tube length }=115 \mathrm{~cm}\end{array}$} & tube, posterior end & 0.05 & 1.22 & 0.007 & & 70 & 1.06 & 0.3 & 3.78 & 4.8 \\
\hline & tube, middle part & nd & 6.25 & 0.037 & & 67 & 0.58 & 0.53 & 0.59 & 21.3 \\
\hline & tube, anterior end & nd & 28.8 & 0.001 & & 185 & 0.44 & 0.36 & 0.78 & 8.6 \\
\hline \multirow{2}{*}{ Nuculana grasslei $(\mathrm{n}=15)$} & whole soft tissues & $64.0 \pm 7.3$ & $56.3 \pm 18.2$ & $20.034 \pm 0$ & $.013 \quad 144$ & $440 \pm 208 \quad 4$. & $4.0 \pm 0.35 \quad 0.7$ & $.77 \pm 0.25$ & $3.9 \pm 2.0$ & $879 \pm 75$ \\
\hline & shell & $1.24 \pm 0.16$ & $2.33 \pm 0.71$ & $1 \quad 0.003 \pm 0$ & .002 & $58 \pm 39$ & $.34 \pm 0.05 \quad 0$. & $0.23 \pm 0.1 \quad 2$. & $2.65 \pm 0.7$ & $16.6 \pm 4.8$ \\
\hline & foot & 0.37 & 3.57 & 0.01 & & 73 & 3.62 & 0.41 & 5.57 & 9.2 \\
\hline Archivesica gigas & gills & 1.22 & 1.01 & 0.02 & & 280 & 1.12 & 1.29 & 21.4 & 42.5 \\
\hline & mantle & 7.29 & 4.14 & 0.08 & & 725 & 4.32 & 0.29 & 4.03 & 45.5 \\
\hline $\begin{array}{l}\text { Archivesica gigas }(\mathrm{n}=1), \\
\text { shell length }=88 \mathrm{~mm}\end{array}$ & shell & 0.03 & 1.16 & 0.00 & & 870 & 3.64 & 0.27 & 0.61 & 8.5 \\
\hline Phelliactis pabista $(\mathrm{n}=1)$ & whole & nd & 8.15 & nd & & 140 & 5.70 & 0.28 & 1.29 & 69.7 \\
\hline & chitin & 0.81 & 1.92 & 0.00 & & 21 & 2.86 & 0.3 & 0.25 & 51.7 \\
\hline Munidopsis alvisca $(\mathrm{n}=1)$ & spawn & 0.44 & 2.65 & nd & & 47 & 0.34 & 0.18 & 0.65 & 39.9 \\
\hline & remaining & 1.43 & 3.92 & 0.02 & & 125 & 4.32 & 0.36 & 1.72 & 122 \\
\hline Spongia $(\mathrm{n}=1)$ & whole & 0.91 & 9.5 & 0.012 & & 225 & 6.64 & 0.97 & 1.67 & 80.7 \\
\hline $\begin{array}{l}\text { Taxon (number of } \\
\text { specimens) }\end{array}$ & Tissue & $\mathrm{Cu}$ & $\mathrm{Fe}$ & $\mathrm{Hg}$ & $\mathrm{Mn}$ & $\mathrm{Pb}$ & $\mathrm{Sb}$ & $\mathrm{Se}$ & $\mathrm{Zn}$ & $\mathrm{C}_{\text {org }}, \%$ \\
\hline & trophosome & $15.4 \pm 2.6$ & $785 \pm 80$ & $1.66 \pm 0.3$ & $10.2 \pm 3.8$ & $\begin{array}{ll}8 & 0.14 \pm 0.08\end{array}$ & $\begin{array}{ll}8 & 4.95 \pm 1.2\end{array}$ & $20.41 \pm 0.1$ & $1255 \pm 27$ & $24.2 \pm 2.3$ \\
\hline & obturaculae & $7.9 \pm 2.7$ & $92 \pm 8$ & $1.21 \pm 0.42$ & $19.3 \pm 7.5$ & $\begin{array}{ll}.5 & 24.6 \pm 11.3\end{array}$ & $3 \quad 8.19 \pm 2.0$ & $0.93 \pm 0.23$ & $3231 \pm 27$ & nd \\
\hline Riftia pachypt & opisthosome & $0.6 \pm 0.2$ & nd & $4.34 \pm 1.35$ & $10.1 \pm 2.4$ & $\begin{array}{ll}.4 & 1.52 \pm 0.16\end{array}$ & $\begin{array}{ll}6 & 0.82 \pm 0.25\end{array}$ & $\begin{array}{ll}5 & 1.31 \pm 0.25\end{array}$ & $5 \quad 410 \pm 46$ & nd \\
\hline & vestimentum & $7.9 \pm 3.2$ & $10 \pm 3$ & $1.43 \pm 0.37$ & $15.5 \pm 5.4$ & $\begin{array}{ll}.4 & 0.47 \pm 0.1\end{array}$ & $1 \quad 5.67 \pm 2.1$ & $0.34 \pm 0.13$ & $3105 \pm 12$ & $22.9 \pm 1.4$ \\
\hline & tube & $11.3 \pm 3.5$ & $102 \pm 14$ & $0.41 \pm 0.23$ & $12.2 \pm 2.5$ & $\begin{array}{ll}.5 & 3.65 \pm 0.93 \\
\end{array}$ & $3 \quad 1.44 \pm 0.2$ & $2 \quad 0.26 \pm 0.1$ & $112 \pm 13$ & $20.3 \pm 1.7$ \\
\hline & trophosome & 34.0 & 463 & 7.81 & 7.8 & 1.10 & 6.33 & 1.84 & 101 & 28.5 \\
\hline & obturaculae & 24.3 & 451 & 0.26 & 17.6 & 0.05 & 11.3 & 4.35 & 380 & 26.1 \\
\hline Riftia & opisthosome & 42.8 & 131 & 1.70 & 13.8 & 0.05 & 13.7 & 1.5 & 175 & 27.5 \\
\hline tube length & vestimentum & 8.7 & 110 & 4.36 & 8.6 & 3.00 & 2.09 & 0.37 & 82 & 27.4 \\
\hline & gonades & 4.6 & 62 & 1.54 & 6.1 & 0.47 & 1.72 & 1.55 & 173 & 25.8 \\
\hline & tube & 26.3 & 112 & 0.27 & 6.2 & 0.75 & 0.74 & 1.6 & 44 & nd \\
\hline & tube, posterior end & 4.8 & nd & 0.17 & 2.9 & 0.73 & 0.21 & 0.42 & 40 & 22.9 \\
\hline $\begin{array}{l}\text { Riftia pachyptila }(\mathrm{n}=1) \text {, } \\
\text { tube length }=115 \mathrm{~cm}\end{array}$ & tube, middle part & 21.3 & 215 & 0.31 & 9.5 & 2.45 & 0.52 & 3.79 & 73 & 21.5 \\
\hline & tube, anterior end & 8.6 & 92 & 0.21 & 5.5 & 3.68 & 4.4 & 1.25 & 42 & 21.1 \\
\hline & whole soft tissues & $879 \pm 75$ & $8905 \pm 765$ & $1.57 \pm 0.32$ & $6.8 \pm 3.2$ & $2 \quad 24.3 \pm 10.2$ & $2 \quad 13.1 \pm 2.8$ & $7.3 \pm 2.1$ & $580 \pm 60$ & nd \\
\hline Nuculana grasslei $(\mathrm{n}=15)$ & shell & $16.6 \pm 4.8$ & $101 \pm 23$ & $0.26 \pm 0.11$ & $5.25 \pm 2.8$ & $.8 \quad 1.56 \pm 0.35$ & $5 \quad 0.53 \pm 0.2$ & $0.09 \pm 0.03$ & $3 \quad 4.6 \pm 1.9$ & $0.6 \pm 0.1$ \\
\hline & foot & 9.2 & 125 & 0.98 & 10.8 & 1.84 & 0.32 & 0.56 & 120 & nd \\
\hline Archivesica gigas $(\mathrm{n}=1)$, & gills & 42.5 & 284 & 0.17 & 8.6 & 1.42 & 1.34 & 1.52 & 3110 & 23.6 \\
\hline & mantle & 45.5 & 452 & 0.44 & 11.5 & 4.1 & 5.4 & 0.54 & 560 & nd \\
\hline $\begin{array}{l}\text { Archivesica gigas }(\mathrm{n}=1) \text {, } \\
\text { shell length }=88 \mathrm{~mm}\end{array}$ & shell & 8.5 & 191 & 0.08 & 56.8 & 2.72 & 0.009 & 0.16 & 20 & nd \\
\hline Phelliactis pabista $(\mathrm{n}=1)$ & whole & 69.7 & 8800 & 0.23 & 172.1 & 70.9 & 1.83 & 1.81 & 3317 & nd \\
\hline & chitin & 51.7 & 51 & 0.18 & 230.0 & 0.17 & 0.26 & 0.15 & 60 & nd \\
\hline Munidopsis alvisca $(\mathrm{n}=1)$ & spawn & 39.9 & 26 & 0.11 & 17.2 & 3.58 & 0.053 & 0.63 & 62 & nd \\
\hline & remaining & 122 & 107 & 0.25 & 367.5 & 7.06 & 0.36 & 1.07 & 53 & nd \\
\hline Spongia $(\mathrm{n}=1)$ & whole & 80.7 & 703 & 0.38 & 2914.9 & 24.7 & 1.11 & 1.81 & 200 & 16.9 \\
\hline
\end{tabular}

n.d.- not determined (not analyzed) 

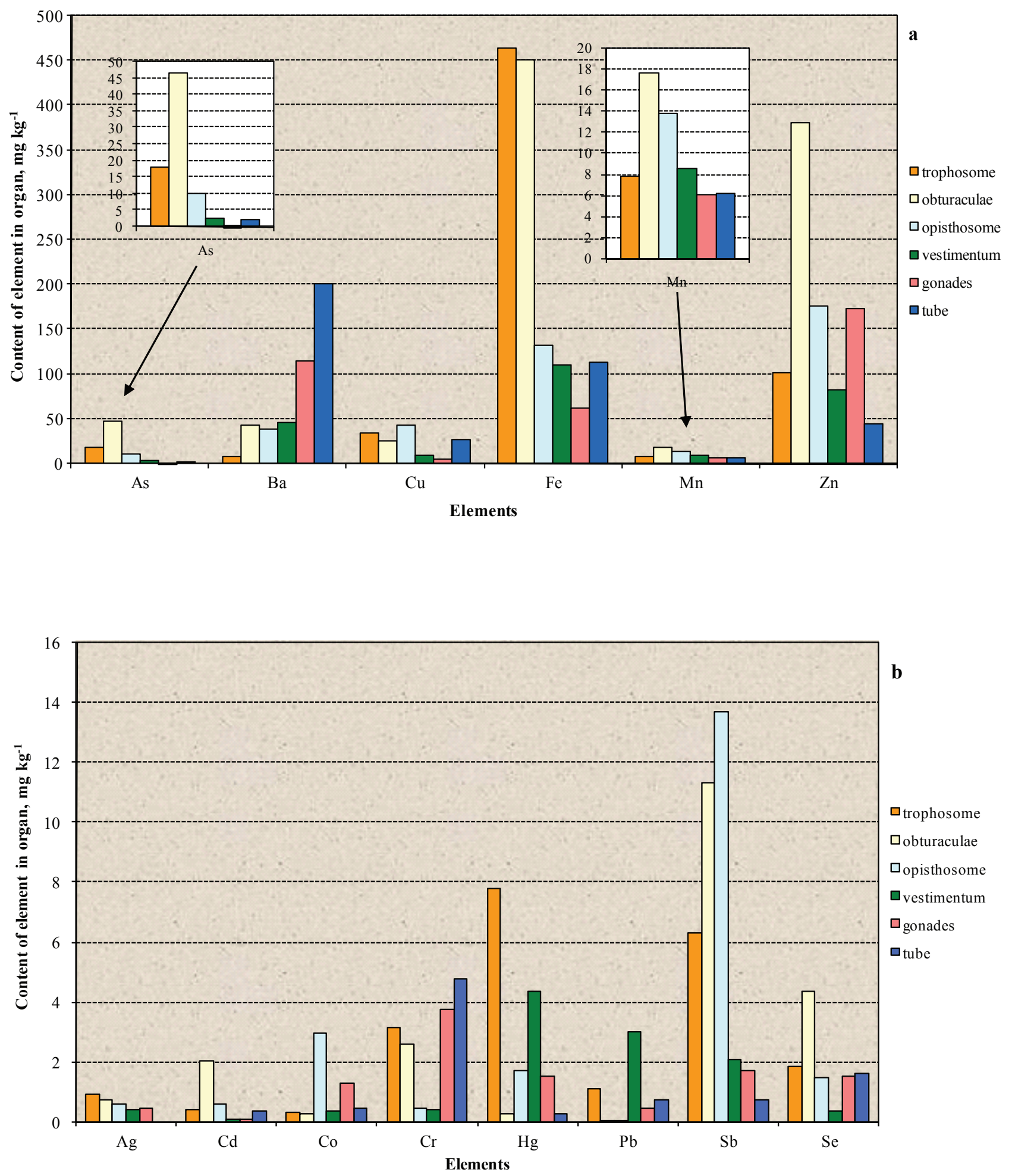

Figure 2. Metal contents ( $\mathrm{mg} \mathrm{kg}^{-1} \mathrm{dry}$ weight) in the different organs of vestimentifera Riftia pachyptila at the Guaymas Basin's vent field: a) As, Ba, Cu, $\mathrm{Fe}, \mathrm{Mn}$ and $\mathrm{Zn}$; b) $\mathrm{Ag}, \mathrm{Cd}, \mathrm{Co}, \mathrm{Cr}, \mathrm{Hg}, \mathrm{Pb}, \mathrm{Sb}$ and $\mathrm{Se}$. 
order of magnitude higher) than in other tissues (Table 3, Figures $3 a, 3 b)$.

The metal distribution in the soft tissues of the second dominant bivalve mollusk Nuculana grasslei is remarkable for having very high or the highest contents of many elements, including: $\mathrm{Fe}\left(8904 \mathrm{mg} \mathrm{kg}^{-1}\right), \mathrm{Ba}\left(1440 \mathrm{mg} \mathrm{kg}^{-1}\right)$, $\mathrm{Cu}\left(873 \mathrm{mg} \mathrm{kg}^{-1}\right), \mathrm{Zn}\left(580 \mathrm{mg} \mathrm{kg}^{-1}\right), \mathrm{Ag}\left(64 \mathrm{mg} \mathrm{kg}^{-1}\right)$, As (56.3 mg kg-1), Pb (24.3 mg kg-1), Sb (13.3 $\left.\mathrm{mg} \mathrm{kg}^{-1}\right)$ and Se $\left(7.3 \mathrm{mg} \mathrm{kg}^{-1}\right)$. As a rule, the difference between metal contents (except Mn) in the soft body compared to the shell was significant, reaching up to two orders of magnitude.

In the whole body of the Phelliactis pabista specimens, which were collected from areas impacted by hot shimmering water, elevated contents of $\mathrm{Cd}\left(5.7 \mathrm{mg} \mathrm{kg}^{-1}\right), \mathrm{Cu}(70 \mathrm{mg} \mathrm{kg}$ $\left.{ }^{1}\right), \mathrm{Fe}\left(8800 \mathrm{mg} \mathrm{kg}^{-1}\right), \mathrm{Mn}\left(172 \mathrm{mg} \mathrm{kg}^{-1}\right), \mathrm{Pb}$ (71 $\left.\mathrm{mg} \mathrm{kg}^{-1}\right)$, and $\mathrm{Zn}\left(3317 \mathrm{mg} \mathrm{kg}^{-1}\right)$ were found. Phelliactis pabista were collected in the microhabitats of the vesicomyid clam Archivesica gigas. Many specimens were attached to the shells of these clams.

In the chitin and remaining tissues (gills) of the Munidopsis alvisca crab, elevated concentrations of $\mathrm{Cu}(122$ $\left.\mathrm{mg} \mathrm{kg}^{-1}\right)$ and $\mathrm{Mn}\left(367 \mathrm{mg} \mathrm{kg}^{-1}\right)$ were detected. These levels were higher than those observed in the organs of Munidopsis alvisca prey Riftia and Archivesica gigas.

In the whole body of Spongia specimens, collected where hot fluids were emitted, maximum Mn content $\left(2915 \mathrm{mg} \mathrm{kg}^{-1}\right)$ was detected, approximately two orders of magnitude higher than in the other organisms. The other chemical elements studied also demonstrate rather high concentrations in Spongia (Table 3). Sponges are filterfeeding organisms that utilize organic matter and bacterial biomass as well as mineral suspensions. Their biochemical functioning and siliceous mineral skeletons lead to the formation of biostructures with very high porosity, which contributes to their effective adsorption and absorption capabilities.

\section{Discussion}

The geochemical environmental conditions of the Southern trough of the Guaymas Basin apparently result in some peculiarities in fluid composition. In particular, Mn concentration is distinctly higher than Fe concentration in hot fluids of the first type compared to warm fluids of the second type. This differs from the hydrothermal vent fluids of the Mid-Atlantic Ridge and $9^{\circ} 50^{\prime} \mathrm{N}$ of the East Pacific Rise, where Fe is found in higher concentrations than $\mathrm{Mn}$ (Douville et al., 2002; Von Damm, 2000). Magnesium is completely absent in pure end-member hydrothermal fluids due to its uptake by basalts during hydrothermal circulation (Von Damm, 1990). The relatively high Mg concentrations in our water samples are evidence of a high degree of fluid dilution with the seawater. On the other hand, the levels of trace metals in these fluids are much lower than in the end-member fluids of the Guaymas hydrothermal vent field
(Von Damm et al., 1985), which also implies that fluids are strongly diluted by seawater during their mixing. We also cannot exclude partial precipitation of particles from the fluids inside a sedimentary cover during neutralization and cooling. The Fe/Mn molar ratios are 5.0 and 0.47 for fluids of the first and second types respectively, with an average $\mathrm{Fe} / \mathrm{Mn}$ ratio of 2.7. This is much lower than the basalt $\mathrm{Fe} / \mathrm{Mn}$ ratio (50-60), but rather close to the $\mathrm{Fe} / \mathrm{Mn}$ of 3 for metalliferrous sediments (Dymond et al., 1973). This suggests that, due to various biogeochemical processes within the sedimentary cover, the behavior of $\mathrm{Fe}$ and $\mathrm{Mn}$ in fluids ascending through the sediment may be altered, resulting in enrichment of Fe relative to $\mathrm{Mn}$ in the first type fluids or vice versa in the second type.

Since hydrothermal vestimentiferas Riftia was first discovered only about 30 years ago, some features of its metabolism are not fully elucidated. The trophosome is known to host intracellular symbiotic bacteria, performing sulfide oxidation and carbon fixation. Based on this, the high $\mathrm{C}_{\text {org }}$ content $(28.53 \%)$ detected in trophosome is quite natural and can be attributed to accumulation of endosymbiotic bacteria. A rather small difference (about 8 $\%$ ) between the highest and lowest $\mathrm{C}_{\text {org }}$ concentrations in the Riftia organs might be attributed, in our opinion, to the presence of bacterial biomass in the form of microbial mats and overgrowth on the Riftia tubes. The vestimentiferan growth rate is known to range from 10 (Fustec et al., 1988) to $50 \mathrm{~cm}$ per year (Tunnicliffe, 1991). Thus, it follows that our examined Riftia individuals are rather young - between one (tube length 10-21 cm) and five (tube length $51 \mathrm{~cm}$ ) years old. Our data do not allow us to examine differences in the trace metal contents of different organs in these two groups; however, data from Ruelas-Inzunza et al. (2005) seem to show that only concentrations of $\mathrm{Cd}$ and $\mathrm{Fe}$ in vestimentum increase with the size of specimens. The rest of the metals did not show any relationship to length. Ruelas-Inzunza et al. (2005) also found that the trophosome is an organ with high accumulation of $\mathrm{Co}, \mathrm{Cu}$ and $\mathrm{Fe}$. Our data support this conclusion for $\mathrm{Cu}$ and $\mathrm{Fe}$. The calculation of average metal contents in two different-sized groups of Riftia shows that the trophosome is a target organ for $\mathrm{Fe}$ (624 mg kg-1), $\mathrm{Cu}\left(24.7 \mathrm{mg} \mathrm{kg}^{-1}\right), \mathrm{Ag}\left(2.19 \mathrm{mg} \mathrm{kg}^{-1}\right)$ and $\mathrm{Hg}\left(4.73 \mathrm{mg} \mathrm{kg}^{-1}\right)$. It should be noted that our data on the distribution of the majority of metals in different Riftia organs are similar in orders of magnitude to earlier published findings for the Guaymas Basin, with the exception of $\mathrm{Cu}$ in the opistosome, $\mathrm{Fe}$ in the vestimentum and $\mathrm{Hg}$ in the trophosome and vestimentum; in these cases our data are approximately one order of magnitude lower (Table 4).

Using data from Tables 3 and 5 (Demina et al., 2007), inter-site comparisons of metal content can be conducted for organisms taken from geochemically different vent fields: the $9^{\circ} 50^{\prime} \mathrm{N}$ EPR and the Guaymas Basin. In Riftia organs the $\mathrm{Mn}$ contents are about 3 times higher in the trophosome and obturaculum and 24 times higher in the tubes of the Guaymas Basin's specimens relative to specimens taken 

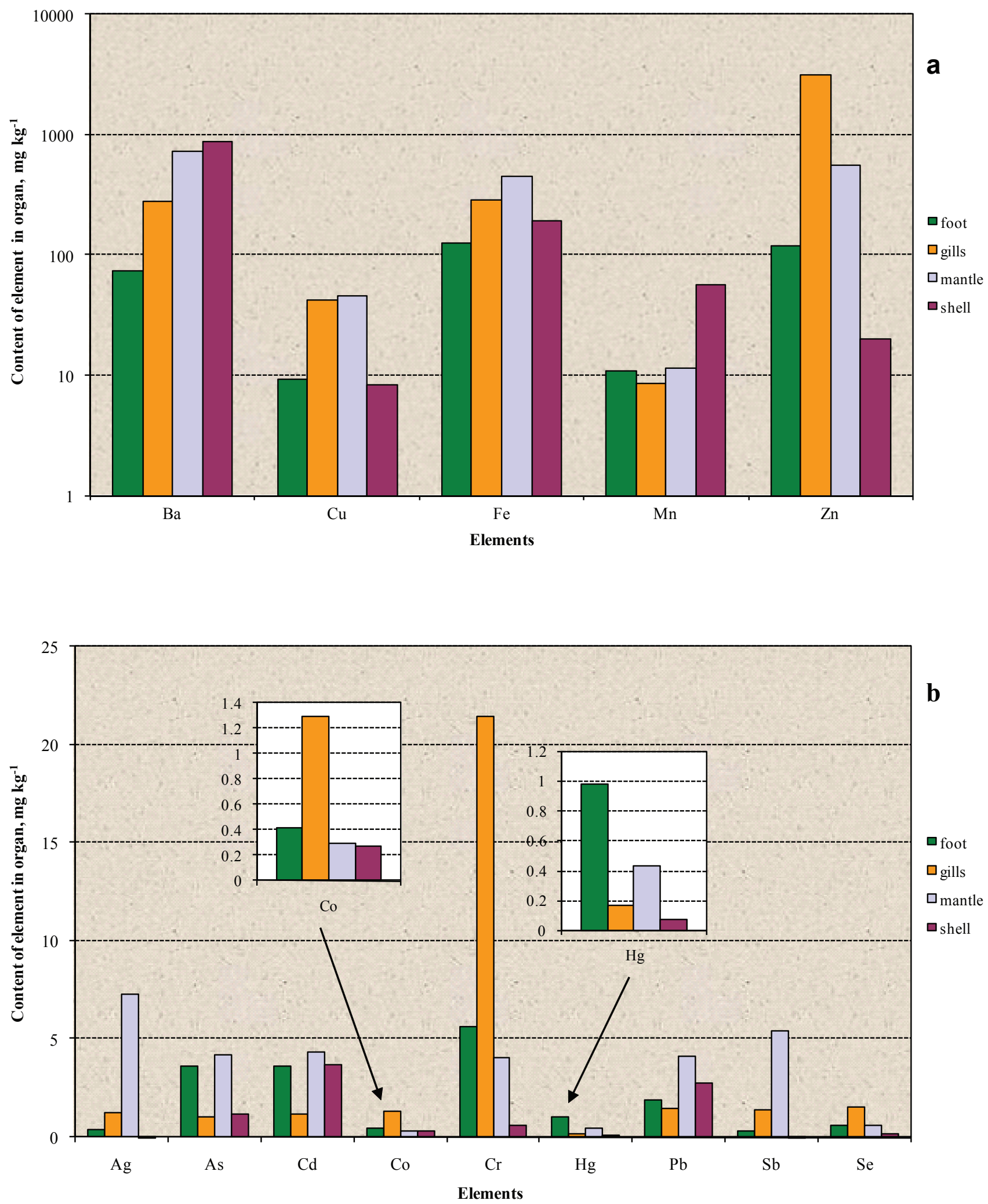

Figure 3. Distribution of metals in organs of vesicomyid clam Archivesica gigas: a) Ba, Cu, Fe, Mn and Zn; b) Ag, As, $\mathrm{Au}, \mathrm{Cd}, \mathrm{Co}, \mathrm{Cr}, \mathrm{Hg}, \mathrm{Pb}, \mathrm{Sb}$ and Se. 
Table 4. Levels of some trace elements ( $\mathrm{mg} \mathrm{kg}^{-1}$ dry weight) in the invertebrates inhabited the Guaymas Basin's hydrothermal vent field, based on published data

\begin{tabular}{|c|c|c|c|c|c|c|c|c|c|c|c|}
\hline Organ & $\mathrm{Ba}$ & $\mathrm{Cd}$ & Co & $\mathrm{Cr}$ & $\mathrm{Cu}$ & $\mathrm{Fe}$ & $\mathrm{Hg}$ & $\mathrm{Mn}$ & $\mathrm{Pb}$ & $\mathrm{Zn}$ & Reference \\
\hline \multicolumn{12}{|c|}{ Vestimetntifera Riftia pachyptila } \\
\hline trophosome & 98 & 1.9 & 2.8 & 2.9 & 13.8 & 493 & n.d. & 0.7 & 9 & 428 & Lein et al., 1989 \\
\hline trophosome & n.d. & 1.7 & 2.2 & 3.4 & 26.4 & 521 & 22.2 & 4.1 & 1.9 & 245 & Ruelas-Inzunza et al., 2005 \\
\hline vestimentum & 74 & 1.5 & 0.1 & 7 & 27 & 4900 & n.d. & 31 & $<5$ & 250 & Lukashin et al., 1990 \\
\hline vestimentum & n.d. & 3.7 & 0.7 & 3.4 & 11.6 & 297 & 22.5 & 6 & 2 & 599 & Ruelas-Inzunza et al., 2005 \\
\hline opistosome & n.d. & 5 & n.d. & 2.1 & 117 & 333 & n.d. & 24 & n.d. & 1613 & Lein et al., 1989 \\
\hline tube & 50 & 1 & 1.5 & $<2$ & 16.7 & 420 & n.d. & 30.7 & 5.4 & 195 & Lukashin et al., 1990 \\
\hline \multicolumn{12}{|c|}{ Vent clam Archivesica gigas } \\
\hline gills & 230 & 11 & 1.5 & 8.3 & 12 & 400 & n.d. & 6.6 & 5 & 1000 & Lein et al., 1989 \\
\hline $\begin{array}{l}\text { whole soft } \\
\text { tissues }\end{array}$ & 350 & 9.5 & 5 & 2.5 & 18 & 290 & n.d. & 11 & 5 & 200 & Lukashin et al., 1990 \\
\hline shells & n.d. & 10 & n.d. & 6 & 10 & 54 & n.d. & 56 & 22 & 135 & Lukashin et al., 1990 \\
\hline \multicolumn{12}{|c|}{ Vent clam Vesicomya gigas } \\
\hline gills & n.d. & 115.2 & n.d. & n.d. & 8.26 & 403 & 4.96 & 18 & 2.89 & 845 & \multirow{2}{*}{ Ruelas-Inzunza et al., 2003} \\
\hline mantle & n.d. & 12.3 & n.d. & n.d. & 29.7 & 277 & 1.1 & 10.6 & 3.67 & 419 & \\
\hline
\end{tabular}

n.d. is not determined (not analyzed)

Table 5. Average content* of some elements in organs of mussels, clams and vestimentiferas from the $9^{\circ} 50^{\prime}$ degree $\mathrm{N}$ hydrothermal field (Demina et al., 2007)

\begin{tabular}{|c|c|c|c|c|c|c|c|c|c|c|c|c|c|c|}
\hline Taxon & Organ & $\mathrm{Ag}$ & As & $\mathrm{Ba}$ & $\mathrm{Cd}$ & Co & $\mathrm{Cr}$ & $\mathrm{Cu}$ & $\mathrm{Fe}$ & $\mathrm{Hg}$ & $\mathrm{Mn}$ & $\mathrm{Pb}$ & $\mathrm{Zn}$ & $\mathrm{C}_{\mathrm{org}}, \%$ \\
\hline \multirow{10}{*}{ Bathymodiolus thermofilus } & \multirow{2}{*}{ gills } & 15.44 & 7.50 & 46 & 4.66 & 42.75 & 5.91 & 166.4 & 214.4 & 0.18 & 4.32 & 0.40 & 120.1 & 27.1 \\
\hline & & 1.64 & 3.22 & 28 & 0.15 & 30.76 & 5.35 & 6.1 & 2.6 & 0.04 & 1.67 & 0.45 & 15.1 & 5.7 \\
\hline & \multirow{2}{*}{ mantle } & 4.58 & 2.23 & 70 & 0.30 & 5.13 & 3.15 & 18.6 & 25.1 & 0.08 & 1.18 & 0.87 & 41.9 & 25.5 \\
\hline & & 2.82 & 2.31 & 15 & 0.39 & 4.49 & 1.07 & 1.2 & 7.7 & 0.04 & 0.11 & 1.15 & 0.2 & 6.8 \\
\hline & \multirow{2}{*}{ foot } & 2.00 & 3.15 & 563 & 0.07 & 6.14 & 32.39 & 5.8 & 36.8 & 0.19 & 2.37 & 1.51 & 30.2 & 23.3 \\
\hline & & 0.09 & 3.73 & 583 & 0.08 & 3.27 & 5.20 & 2.3 & 35.0 & 0.20 & 0.43 & 0.78 & 1.6 & 3.6 \\
\hline & \multirow{2}{*}{ remaining } & 4.68 & 2.37 & 30 & 0.85 & 6.08 & 1.27 & 27.9 & 101.3 & 0.14 & 1.12 & 2.36 & 65.6 & 29.2 \\
\hline & & 0.10 & 0.21 & 18 & 0.84 & 2.06 & 0.72 & 13.4 & 32.0 & 0.12 & 0.11 & 3.28 & 18.7 & 6.3 \\
\hline & \multirow{2}{*}{ shell } & 0.02 & 1.98 & 67 & 0.21 & 2.44 & 0.40 & 7.6 & 52.1 & 0.05 & 4.41 & 6.98 & 8.2 & 2.4 \\
\hline & & 0.00 & 2.16 & 62 & 0.26 & 0.69 & 0.19 & 4.5 & 2.2 & 0.01 & 2.07 & 3.74 & 5.9 & 1.6 \\
\hline \multirow{5}{*}{ Archivesica gigas } & gills & 2.28 & 9.43 & 94 & 1.55 & 3.16 & 74.0 & 66.8 & 377.9 & 0.05 & 3.78 & 1.73 & 260.2 & 29.5 \\
\hline & mantle & 3.79 & 3.79 & 34 & 2.06 & 3.63 & 10.8 & 32.9 & 170.0 & 0.06 & 49.22 & 8.36 & 320 & 23.8 \\
\hline & foot & 4.64 & 4.64 & 30 & 0.12 & 3.42 & 1.54 & 18.3 & 140.0 & 0.07 & 2.53 & 102.1 & 400 & 28.3 \\
\hline & remaining & 7.27 & 3.61 & 23 & 1.1 & 2.45 & 3.19 & 21.4 & 100.8 & 0.04 & 4.17 & 1.61 & 145.1 & 26.0 \\
\hline & shell & 0.03 & 1.03 & 42 & 0.01 & 2.8 & 1.32 & 4.68 & 24.8 & 0.05 & 1.94 & 8.63 & 12 & 0.3 \\
\hline \multirow{10}{*}{ Riftia pachyptila } & \multirow{2}{*}{ trophosome } & 3.83 & 5.82 & 39 & 0.23 & 17.05 & 1.09 & 23.3 & 389.3 & 0.51 & 3.19 & 11.95 & 157.5 & 28.9 \\
\hline & & 4.13 & 1.87 & 15 & 0.19 & 13.48 & 0.70 & 23.8 & 171.0 & 0.22 & 2.45 & 17.71 & 97.9 & 5.1 \\
\hline & \multirow{2}{*}{ obturaculum } & 1.52 & 2.13 & & 0.72 & 9.42 & 4.62 & 18.9 & 1035 & 0.14 & 13.06 & 8.44 & 355.3 & 24.8 \\
\hline & & 1.16 & 0.88 & & 0.62 & 8.93 & 6.15 & 8.3 & 760.1 & 0.13 & 7.53 & 11.83 & 129.7 & 4.3 \\
\hline & \multirow{2}{*}{ opistosome } & 3.67 & 2.96 & 608 & 0.10 & 3.21 & 4.02 & 20.0 & 232.1 & 0.74 & 166.37 & 7.51 & 166.4 & 32.7 \\
\hline & & 2.75 & 2.60 & 796 & 0.01 & 1.41 & 1.83 & 19.8 & 14.2 & 0.11 & 63.88 & 5.03 & 63.9 & 0.0 \\
\hline & \multirow{2}{*}{ vestimentum } & 2.22 & 1.29 & 75 & 0.25 & 13.28 & 2.03 & 13.1 & 164.0 & 0.51 & 31.32 & 2.71 & 72.0 & 24.5 \\
\hline & & 1.87 & 0.38 & 49 & 0.25 & 8.49 & 1.22 & 12.5 & 48.9 & 0.37 & 38.82 & 0.55 & 22.0 & 1.0 \\
\hline & \multirow{2}{*}{ tube } & 0.56 & 2.12 & 50 & 0.23 & 4.01 & 2.04 & 18.9 & 118.0 & 0.29 & 0.31 & 3.47 & 26.1 & 23.6 \\
\hline & & 0.20 & 0.79 & 14 & 0.27 & 0.49 & 2.15 & 10.1 & 77.5 & 0.19 & 0.02 & 5.45 & 9.4 & 1.6 \\
\hline
\end{tabular}

* metal content - in $\mathrm{mg} \mathrm{kg}^{-1}$ dry weight; for each organ the first line is average content, the second one is \pm standard deviation. 
from the $9^{\circ} 50^{\prime} \mathrm{N}$ EPR. A similar excess in Guaymas Basin's specimens was found for $\mathrm{As}$ ( 2 to 12 times higher), $\mathrm{Cd}$ (4 to 18 times higher), and $\mathrm{Hg}$ (up to 9 times higher). Meanwhile $\mathrm{Cu}, \mathrm{Fe}$ and $\mathrm{Zn}$ showed similar levels in both cases, but the $\mathrm{Ag}, \mathrm{Co}$ and $\mathrm{Pb}$ contents were several times lower in the Guaymas Basin's Riftia specimens. A rather high standard deviation of average contents of many metals obviously testifies the lack of significant difference in metal contents in specimens of these two fields.

A comparison of metal levels in bivalves showed that only in the external organs (gills and shells) there is a noticeable accumulation (an order of magnitude higher) of essential metals ( $\mathrm{Fe}, \mathrm{Mn}$ and $\mathrm{Zn}$ ) in the Guaymas Basin's specimens. Hg contents in the soft tissues are 10 times higher in Guaymas Basin's specimens than in specimens collected from the $9^{\circ} 50^{\prime} \mathrm{N}$ EPR. Contents of these metals are at similar levels in both cases for other organs. Specimens from the $9^{\circ} 50^{\prime} \mathrm{N}$ EPR contain only three elements (As in gills, $\mathrm{Ag}$ in foot and Co in mantle, foot and shell) at about 10 times higher than the level of Guaymas Basin's specimens.

Thus, we cannot conclude that levels of the majority of metals in organism tissues are a reflection of their levels in the fluids, since majority of metals show much higher concentrations in the fluids of the $9^{\circ} 50^{\prime} \mathrm{N}$ EPR hydrothermal region in comparison to the Guaymas Basin (Von Damm, 2000; Von Damm et al., 1985).

The gills of the vesicomyid clams are known to contain endosymbiotic bacteria. Along with symbiotrophy, a nutritional strategy of this clam may include suspensionfiltering feeding. High amounts of $\mathrm{Cd}, \mathrm{Cu}, \mathrm{Fe}, \mathrm{Mn}, \mathrm{Pb}, \mathrm{S}$, and $\mathrm{Zn}$ were detected in the whole soft tissues (where gills have a larger contribution of biomass compared to other organs) of a similar vesicomyid clam, Archivesica gigas, from $21^{\circ} \mathrm{N}$ at the East Pacific Rise (Roesijadi and Crecelius, 1984). The data of Ruelas-Inzunza et al. (2003) on metal distribution in different tissues of the vent clam Vesicomya gigas from the Guaymas Basin indicate that the highest amounts of $\mathrm{Cd}, \mathrm{Fe}, \mathrm{Hg}, \mathrm{Mn}$ and $\mathrm{Zn}$ were detected in the gills, while highest contents of $\mathrm{Cu}$ and $\mathrm{Pb}$ occurred mainly in the mantle. The difference between $\mathrm{Cd}$ concentrations in the gills and mantle did not exceed one order of magnitude, while for the rest of the metals it was only 1.5-4 times. Slightly greater amounts of metal accumulation were shown in the gills of Archivesica gigas, relative to other soft tissues (Lein et al., 1989; Lukashin et al., 1990). According to our data, $\mathrm{Ag}, \mathrm{As}, \mathrm{Au}, \mathrm{Cd}, \mathrm{Cu}, \mathrm{Fe}, \mathrm{Pb}$, and $\mathrm{Sb}$ are accumulated in mantle to a greater extent than in the gills of the vesicomyid clam Archivesica gigas (Figure 3). This might be reasonably explained by a distinguishing feature of the Guaymas Basin's environmental conditions: a significant amount of production in the bacterial mats, covering sulfide ores (27 $\mathrm{mg} \mathrm{C}_{\text {org }} \mathrm{m}^{-2} \mathrm{day}^{-1}$, Lein et al., 1988) and contained in the upper $50 \mathrm{~cm}$ sedimentary layer $\left(91 \mathrm{mg} \mathrm{C}_{\text {org }} \mathrm{m}^{-2} \mathrm{day}^{-1}\right.$, Gal'chenko et al., 1989) that is several times higher than in the other hydrothermal fields. We may suppose that in such an environment, which is highly enriched in organic carbon, the clam population may receive nutrients by suspensionfeeding to a greater extent than is observed as a result of symbiotrophy. In this case, in a mantle where chemical elements are assimilated mainly from food rather than from water via gills, metals could be highly accumulated relative to gills.

The shells of the vesicomyid clam Archivesica gigas are an important target for $\mathrm{Ba}, \mathrm{Mn}$, and to a lesser extent of Fe (Figure 3a), however for other metals, they play only a small role. Taking into account the large mass of the shell relative to the soft tissue of clams (in which the former may reach one order of magnitude higher that the latter), we can suggest that shells, which have accumulated trace metals during biomineralization and adsorption, might serve as a great reservoir for many metals. The second abundant bivalve mollusk Nuculana grasslei lives on substratum saturated with hydrocarbons (Allen, 1993). Unlike similar species, this animal has an extremely thick periostratum (an exterior part of the shell) that is considered to be an adaptation to functioning in an acidic environment enriched in sulfides. Its nutritional source has not yet been studied completely, but some researchers regard Nuculana grasslei as a symbiotrophic organism containing bacteria in its gills that can combine symbiotrophy with filter-feeding. This might lead to a significant bioaccumulation of a majority of metals in the whole body of Nuculana grasslei.

The high levels of some essential metals $(\mathrm{Cu}$ and $\mathrm{Mn})$ in the soft tissues of the Munidopsis alvisca crab seem to be caused by metabolic peculiarities as well as type of feeding, namely, preying on other organisms such as the symbiotrophic Riftia pachyptila and the clams Archivesica gigas and Nuculana grasslei. Phelliactis pabista, which are typically predators, can scavenge both fragments of bacterial mats and organic matter into the vent fields and thus might enhance their metal bioaccumulation. It is important to note that Kádár et al. (2007) revealed trophic level-specific variations in essential metal accumulation in the Menez Gwen hydrothermal community of the Mid Atlantic Ridge, showing a general trend of biomagnification of $\mathrm{Cu}, \mathrm{Fe}$, and $\mathrm{Zn}$ from primary producers (endosymbiont bacteria) to primary (symbiont reliant species and filter-feeders) and secondary consumers (predators and scavengers).

The considerable Mn accumulation (much higher than other metals) in Spongia might be caused by the predominance of $\mathrm{Mn}$ in the water column, influenced by fluids of the first type, compared to other metals. In the body of Spongia, the Fe/Mn ratio is 0.24 , on the same order of magnitude as fluids of the first type (0.5).

As one can see from Table 3, Mn content in the majority of dominant organisms studied is considerably lower than $\mathrm{Fe}$ content (from one to two orders of magnitude). In the different tissues of the dominant animals vestimentifera Riftia, vesicomyidae clam Archivesica gigas and bivalve mollusk Nuculana, the Fe/Mn ratio varies from 0.8 to 1309 . The lower values $(\leq 20)$ were detected in exterior organs such as the tubes of Riftia and the shells of Archivesica 
gigas. The higher values were found in the interior organs, especially those linked with endosymbiotic bacteria, which includes the trophosome of Riftia and the gills of the clam Archivesica gigas. The highest Fe/Mn ratio was found in the soft tissues of the bivalve mollusk Nuculana. It should be mentioned that $\mathrm{Fe} / \mathrm{Mn}$ ratios in our fluid samples vary from 0.47 to 5.0. This differentiation in Fe/Mn ratios seemingly reflects the different forms (or species) of Fe and $\mathrm{Mn}$, which determine their bioavailability. Due to its slower oxidationreduction kinetics, $\mathrm{Mn}$ is able to exist in the dissolved form of $\mathrm{Mn}(+2)$ longer than Fe, where it is utilized by bacteria and involved in relatively rapid microbially catalyzed $\mathrm{Mn}$ oxidation followed by formation of bacterial aggregates that are not commonly assimilated by benthic organisms (Campbell et al., 1988). Bacterial aggregates are taken up by zooplankton, followed by excretion of the Mn-enriched fecal pellets found in the settling material taken by sediment traps (Tambiev and Demina, 1992). Possibly, this process may lead to additional enrichment in Mn of the surface sediments, which in turn provides the benthic flux of $\mathrm{Mn}$.

Studies of the trace metal levels of marine mollusks from areas of the Gulf of California influenced by mining, agriculture and urban activities have shown that areas that are apparently pristine or have few anthropogenic activities have a higher content of metals such as $\mathrm{Cu}, \mathrm{Fe}$ and $\mathrm{Pb}$ in soft tissues (Table 6) (Cadena-Cárdenas et al., 2008). Comparison of these data with levels of metal content in the soft tissues of Nuculana grasslei presented in this paper allows us to conclude that $\mathrm{Pb}$ and $\mathrm{Hg}$ levels in mollusks from the Guaymas Basin are almost one order of magnitude higher than the levels observed in mollusks from polluted areas of the Gulf of California, whereas $\mathrm{Fe}, \mathrm{Zn}$, and $\mathrm{Cu}$ did not reveal any significant differences. Mn contents in mollusks from both contaminated and pristine areas are essentially higher than Mn contents in vent clams. In our opinion, this suggests the importance of the geochemical features of the Guaymas Basin, namely, the low fraction of bioavailable $\mathrm{Mn}$ in the water column, which leads to relatively low Mn content in the tissues of organisms despite the very high concentration of total dissolved Mn in the microhabitat. The latter can be confirmed by the low concentration factor $\mathrm{F}_{\mathrm{c}}$ (ratio of metal content in an organism to its concentration in the surrounding water) of $\mathrm{Mn}$ in the whole body of symbiotrophic animals: $\mathrm{F}_{\mathrm{c}}$ is only 5 and 66 in Riftia pachyptila and Nuculana grasslei respectively (Table 7). On the contrary, $\mathrm{F}_{\mathrm{c}}$ of $\mathrm{Mn}$ in the filter-feeding and preying organisms reaches up to $2 \cdot 10^{3}$. For the rest of metals $F_{c}$ varies within three orders of magnitude - from 30 $(\mathrm{Co})$ to $3 \cdot 10^{4}(\mathrm{Cd})$. This apparently testifies a selectivity of trace element bioaccumulation by the organisms which is determined by metal bioavailability independently of metal concentration in the water column, as well as by the feeding type of taxon. Values of $F_{c}$ for different organisms of the vent community of the Menez Gwen hydrothermal field were from $7 \cdot 10^{3}$ to $8 \cdot 10^{4}$ for $\mathrm{Fe}$, from $10^{3}$ to $3 \cdot 10^{4}$ for $\mathrm{Cu}$, and from $5 \cdot 10^{3}$ to $2 \cdot 10^{5}$ for Zn (Kádár et al., 2007), being similar to our data (Table 7).

\section{Conclusions}

The bioaccumulation of heavy metals in the Guaymas Basin hydrothermal vent fields occurs under very specific biogeochemical conditions associated with thick sedimentary cover, high biological productivity and high bacterial production of organic carbon. In such conditions, the target organs of many metals are not only organs containing endosymbiotic bacteria (the trophosome of vestimentifera Riftia or the gills of vesicomyid clam Archivesica) but also other organs of these organisms (such as the obturaculae and opisthosome of Riftia and the mantle of Archivesica) and even other taxonomic groups of invertebrates (Phelliactis pabista, Sponge, Munidopsis alvisca) that do not bear endosymbiotic bacteria. Possibly due to a combination of symbiotrophy with suspension-feeding, the body of the bivalve mollusk Nuculana grasslei is highly enriched relative to the shell in all the metals studied. While the lowest contents for a majority of metals were found in the shells of clams, however the masses of the shells as a rule are much higher than those of the soft tissues, and for the mentioned reason we suggest that shells might serve as a great reservoir for many metals.

Based on the variability of $\mathrm{Fe} / \mathrm{Mn}$ molar ratios in diluted fluids and different tissues of organisms from the hydrothermal vent areas, we can assume that Fe and $\mathrm{Mn}$ are subjected to a fractionation during bioaccumulation processes. The apparent reason for this behavior might be the different chemical speciation of Fe and $\mathrm{Mn}$, which determine the low bioavailability of Mn for symbiotrophic organisms. There were no significant differences between the $\mathrm{Cd}, \mathrm{Cu}, \mathrm{Fe}, \mathrm{Hg}, \mathrm{Pb}$, and $\mathrm{Zn}$ levels in the Guaymas Basin vent clams versus the bivalve mollusks from polluted areas of the Gulf of California, which suggests the importance of the heavy metal bioavailable fraction rather than their total content in the bioaccumulation.

\section{Acknowledgments}

The authors are grateful to the crew of the R/V 49-th cruise "Akademik Mstislav Keldysh", Prof. Alla Lein for collection of the fluid samples, and Dr. Vyacheslav Gordeev for his help with the flame atomic absorption analyses of samples. The principal financial support for this study was obtained from Russian Foundation of Basic Research, project 05-04-49413 "Trophical structure of deep-sea hydrothermal communities of the World Ocean (reconstruction based on stable isotopes and chemical analyses)". On the final stage of the data treatment and preparation of the manuscript this study was also partially supported by Mexican CONACyT - Ciencia Básica research grant CB-2005-01-50421 "The evaluation of the role of 
Table 6. Levels of some heavy metal contents ( $\mathrm{mg} \mathrm{kg}^{-1} \mathrm{dry}$ weight) in the soft tissues of the mollusks from anthropogenically polluted and pristine areas of the Gulf of California.

\begin{tabular}{|c|c|c|c|c|}
\hline Metal & Range & Bivalve species & Area & Reference \\
\hline \multirow{7}{*}{$\mathrm{Fe}$} & $2231-2311$ & clams Chione subrugosa and Tellina sp. & Pabellón-Atlata wetland system in Sinaloa & Páez-Osuna et al., 1993 \\
\hline & $150-700$ & mussel M.strigata & Estero de Urias, Sinaloa & Ruelas-Inzunza and Páez-Osuna, 2000 \\
\hline & $85.6-397$ & clams C.gnidia and L.elatum & \multirow{3}{*}{$\begin{array}{l}\text { Guaymas Bay, Sonora (contaminated area) } \\
\text { near the phosphorite mine La Paz } \\
\text { pristine (far from this mine) }\end{array}$} & Méndez et al., 2002 \\
\hline & $323-438$ & clam Meganitaria squalida & & \multirow{2}{*}{ Méndez et al., 2006} \\
\hline & $154-558$ & cram Megaptuarta squaltaa & & \\
\hline & $189-572$ & $\begin{array}{l}\text { clams Ch. californiensis, M.squalida, } \\
\text { L.elatum }\end{array}$ & \multirow{2}{*}{$\begin{array}{l}\text { different localities of the Gulf of Cali- } \\
\text { fornia }\end{array}$} & \multirow{2}{*}{ Cadena-Cárdenas et al., 2008} \\
\hline & $150-369$ & mussel M.edulis & & \\
\hline \multirow{8}{*}{$\mathrm{Zn}$} & $25-1247$ & clam Chione californiensis & \multirow{3}{*}{ the southern Gulf of California } & \multirow{3}{*}{ Páez-Osuna et al., 1993} \\
\hline & $64-1218$ & clam Chione subrugosa & & \\
\hline & $64-1944$ & clam Tellina sp. & & \\
\hline & 200 (mean) & mussel M.strigata & the southern Gulf of California & Ruelas-Inzunza and Páez-Osuna, 2000 \\
\hline & $92.4-246$ & clams C.gnidia and L.elatum & Guaymas Bay, Sonora (contaminated area) & Méndes et al., 2002 \\
\hline & up to 64,6 & clam Megapitaria squalida & La Paz Bay (pristine area) & Méndes et al., 2006 \\
\hline & $49.8-91.8$ & $\begin{array}{l}\text { clams Ch. californiensis, M.squalida, } \\
\text { L.elatum }\end{array}$ & \multirow{2}{*}{$\begin{array}{l}\text { different localities of the Gulf of Cali- } \\
\text { fornia }\end{array}$} & \multirow{2}{*}{ Cadena-Cárdenas et al., 2008} \\
\hline & $47.9-94.3$ & mussel M.edulis & & \\
\hline \multirow{8}{*}{$\mathrm{Cu}$} & $4-5$ & mollusks & pristine areas along the Gulf of California & \multirow{3}{*}{ Páez-Osuna et al., 1993} \\
\hline & up to 82 & $\begin{array}{l}\text { mussel M.strigata, clams Chione cali- } \\
\text { forniensis }\end{array}$ & \multirow[t]{2}{*}{ some areas along the Gulf of California } & \\
\hline & & Chione subrugosa and Tellina sp. & & \\
\hline & 13.4 (mean) & clams & Colorado River delta & García-Hernández et al., 2001 \\
\hline & $4.78-23.04$ & clams C.gnidia and L.elatum & Guaymas Bay (contaminated area) & Méndez et al., 2002 \\
\hline & up to 8 & clam Megapitaria squalida & La Paz Bay (pristine area) & Méndez et al., 2006 \\
\hline & $3.9-181$ & $\begin{array}{l}\text { clams Ch. californiensis, M.squalida, } \\
\text { L.elatum }\end{array}$ & different localities of the Gulf of Cali- & Cadena-Cárdenas et al., 2008 \\
\hline & $6.1-49.6$ & mussel M.edulis & & \\
\hline \multirow{5}{*}{$\mathrm{Pb}$} & $0.51-4.03$ & clams C.gnidia and L.elatum & Guaymas Bay, Sonora (contaminated area) & Méndez et al., 2002 \\
\hline & up to 7.8 & clam Megapitaria squalida & La Paz Bay (pristine area) & Méndez et al., 2006 \\
\hline & 3,1 (mean) & mussel Mytella strigata & $\begin{array}{l}\text { south-eastern Gulf of California, Urias } \\
\text { estuary }\end{array}$ & Soto-Jiménez et al., 2008 \\
\hline & $<0.03-9.2$ & $\begin{array}{l}\text { clams Ch. californiensis, M.squalida, } \\
\text { L.elatum }\end{array}$ & \multirow{2}{*}{$\begin{array}{l}\text { different localities of the Gulf of Cali- } \\
\text { fornia }\end{array}$} & \multirow[t]{2}{*}{ Cadena-Cárdenas et al., 2008} \\
\hline & $0.27-5.8$ & mussel M.edulis & & \\
\hline \multirow{7}{*}{$\mathrm{Cd}$} & 3.8 & clam Chione californiensis & \multirow{3}{*}{ Pabellón-Altata wetland system in Sinaloa } & \multirow{3}{*}{ Páez-Osuna et al., 1993} \\
\hline & 3.5 & clam Chione subrugosa & & \\
\hline & 8.7 & clam Tellina sp. & & \\
\hline & $0.21-1.28$ & clams C.gnidia and L.elatum & Guaymas Bay, Sonora (contaminated area) & Méndez et al., 2002 \\
\hline & 11.1 & clam Megapitaria squalida & La Paz Bay (pristine area) & Méndez et al., 2006 \\
\hline & $0.42-4.66$ & $\begin{array}{l}\text { clams Ch. californiensis, M.squalida, } \\
\text { L.elatum }\end{array}$ & \multirow{2}{*}{$\begin{array}{l}\text { different localities of the Gulf of Cali- } \\
\text { fornia }\end{array}$} & \multirow[t]{2}{*}{ Cadena-Cárdenas et al., 2008} \\
\hline & $2.42-4.05$ & mussel M.edulis & & \\
\hline \multirow{7}{*}{$\mathrm{Mn}$} & 69 & clam Chione californiensis & \multirow{3}{*}{ Pabellón-Altata wetland system in Sinaloa } & \multirow{3}{*}{ Páez-Osuna et al., 1993} \\
\hline & 80 & clam Chione subrugosa & & \\
\hline & 43 & clam Tellina sp. & & \\
\hline & $1.59-26.9$ & clams C.gnidia and L.elatum & Guaymas Bay, Sonora (contaminated area) & Méndez et al., 2002 \\
\hline & 14.1 (mean) & clam Megapitaria squalida & La Paz Bay (pristine area) & Méndez et al., 2006 \\
\hline & $1.21-3.68$ & $\begin{array}{l}\text { clams Ch. californiensis, M.squalida, } \\
\text { L.elatum }\end{array}$ & different localities of the Gulf of Cali- & Cadena-Cárdenas et al. 2008 \\
\hline & $0.53-3.12$ & mussel M.edulis & & \\
\hline $\mathrm{Hg}$ & $\begin{array}{c}0-063 \\
(\text { mean })\end{array}$ & clam Chione subrugosa & south-eastern Gulf of California & Green-Ruiz et al. 2005 \\
\hline & 0.23 & oyster Craassostrea gigas & & \\
\hline
\end{tabular}


Table 7. Heavy metal content $\left(\mathrm{C}_{\mathrm{m}}\right)$ in the whole organisms and their bioconcentration factors $\left(\mathrm{F}_{\mathrm{c}}\right)$ at the Guaymas Basin Southern trough.

\begin{tabular}{|c|c|c|c|c|c|c|c|c|c|c|c|c|c|c|}
\hline Species & Feeding type & & $\mathrm{Ag}$ & As & $\mathrm{Cd}$ & $\mathrm{Co}$ & $\mathrm{Cr}$ & $\mathrm{Cr}$ & $\mathrm{Cu}$ & $\mathrm{Fe}$ & Mn & $\mathrm{Pb}$ & $\mathrm{Sb}$ & $\mathrm{Zn}$ \\
\hline \multirow{2}{*}{$\begin{array}{c}\text { Vestimentifera } \\
\text { Riftia pachyptila }\end{array}$} & \multirow{2}{*}{ Chemoautotrophy } & $\mathrm{C}_{\mathrm{m}}$ & 0.84 & 9.9 & 2.24 & 0.9 & 1.8 & 1.8 & 15.6 & 259 & 11.7 & 5.2 & 5.3 & 163 \\
\hline & & $\mathrm{F}_{c}^{\mathrm{m}}$ & $4 \cdot 10^{3}$ & $2 \cdot 10^{2}$ & $10^{4}$ & 82 & 45 & 45 & $4 \cdot 10^{2}$ & $2 \cdot 10^{2}$ & 5 & $6 \cdot 10^{2}$ & $10^{3}$ & $8 \cdot 10^{3}$ \\
\hline \multirow{2}{*}{$\begin{array}{l}\text { Bivalve mollusk } \\
\text { Nuculana grasslei }\end{array}$} & \multirow{2}{*}{ Chemoautotrophy? } & $\mathrm{C}_{\mathrm{m}}$ & 7.52 & 7.73 & 0.71 & 0.4 & 2.8 & 2.8 & 102 & 980 & 5.4 & 3.83 & 1.78 & 61.8 \\
\hline & & $\mathrm{F}_{\mathrm{c}}^{\mathrm{m}}$ & $3 \cdot 10^{3}$ & $4 \cdot 10^{2}$ & $2 \cdot 10^{3}$ & 30 & $10^{2}$ & $10^{2}$ & $1 \cdot 10^{3}$ & $2 \cdot 10^{3}$ & 66 & $10^{3}$ & $3 \cdot 10^{2}$ & 50 \\
\hline \multirow{2}{*}{ Actinia Actinaria } & \multirow{2}{*}{ Filter-feeding, predator } & $\mathrm{C}_{\mathrm{m}}$ & - & 8.2 & 5.7 & 0.3 & 1.3 & 1.3 & 69.7 & 8800 & 172 & 71 & 1.8 & 3317 \\
\hline & & $\mathrm{F}_{\mathrm{c}}^{\mathrm{m}}$ & - & $10^{3}$ & $10^{4}$ & 30 & 50 & 50 & $4 \cdot 10^{3}$ & $2 \cdot 10^{4}$ & $2 \cdot 10^{3}$ & $2 \cdot 10^{4}$ & $3 \cdot 10^{2}$ & $3 \cdot 10^{3}$ \\
\hline \multirow{2}{*}{ Sponge Spongia } & \multirow{2}{*}{ Filter-feeding } & $\mathrm{C}_{\mathrm{m}}$ & 0.91 & 9.5 & 6.64 & 1 & 1.7 & 1.7 & 81 & 703 & 2915 & 24.7 & 1.1 & 200 \\
\hline & & $\mathrm{F}^{\mathrm{m}}$ & $4 \cdot 10^{3}$ & $2 \cdot 10^{2}$ & $3 \cdot 10^{4}$ & $10^{2}$ & 40 & 40 & $2 \cdot 10^{3}$ & $10^{3}$ & $10^{3}$ & $3 \cdot 10^{3}$ & $3 \cdot 10^{2}$ & $10^{4}$ \\
\hline
\end{tabular}

$\mathrm{C}_{\mathrm{m}}=$ metal content in the whole organism ( $\mathrm{mg} \mathrm{kg}^{-1}$ dry weight), calculated from the concentrations of each metal in organs, constitutioning whole body, on the base of the percentage of mass of each organ.

$\mathrm{F}_{\mathrm{c}}=\mathrm{C}_{\mathrm{m}} / \mathrm{C}_{\text {water }}$

the zooplankton and suspended particulate matter in the biogeochemistry of the trace elements in the central region of the Gulf of California".

\section{References}

Allen, J.A., 1993, A new deep-water hydrothermal species of Nuculana (Bivalvia: Protobranchia) from the Guaymas Basin: Malacologia, $35,141-151$.

Anonymous, 1995, Seafloor Hydrothermal Systems.Physical, Chemical, Biological, and Geological Interactions, in Humphris, S.E., Zierenberg, R.A., Mullineaux, L.S., Thompson, R.E., (eds.), American Geophysical Union, Washington, $466 \mathrm{p}$.

Bogdanov, Y.A., Lisitzin, A.P., Sagalevitch, A.M., Gurvich, E.G., 2004 Hydrothermal ore formation at the ocean floor: Moscow, Russia, Nauka, 528 p. (in Russian)

BRIDGE Workshop Report No 4, 1994, Diversity of Vent Ecosystems (DOVE): Plymouth, UK, Marine Biological Association.

Cadena-Cárdenas, L., Méndez-Rodríguez, L., Zenteno-Savín, T., GarcíaHernández, J., Acosta-Vargas, B., 2008, Heavy metal levels in marine molluscs from areas with, or without, minine activities along the Gulf of California, Mexico: Archives of Environmental Contamination and Toxicology, DOI 10.1007/s00244-008-9236-0.

Calvert, S.E., 1966, Accumulation of diatomaceous silica in the sediments of the Gulf of California: Geological Society of America Bulletin, 77, 569-596.

Campbell, A.C., Gieskes, J.M., Lupton, J.E., Londsdale, P.F., 1988 , Manganese geochemistry in the Guaymas Basin, Gulf of California: Geochimica et Cosmochimica Acta, 52, 345-357.

Carriquiry, J.D., Sánchez, A., 1999, Sedimentation in the Colorado River delta and Upper Gulf of California after nearly a century of discharge loss: Marine Geology, 158, 125-145.

Carriquiry, J., Sánchez, A., Camacho-Ibar V.F., 2001, Sedimentation in the northern Gulf of California after cessation of the Colorado River discharge: Sedimentary Geology, 144, 37-62.

De la Lanza-Espino, G., Soto, L.A., 1999, Sedimentary geochemistry of hydrothermal vents in Guaymas Basin, Gulf of California, Mexico: Applied Geochemistry, 14, 499-510.

Demina, L.L., Galkin, S.V., Lein, A.Y., Lisitsyn, A.P., 2007, First data on trace element composition of benthic organisms from the $9^{\circ} 50^{\circ} \mathrm{N}$ hydrothermal field, East Pacific Rise: Doklady Earth Sciences, 415, 905-907.

Douville, E., Charlou, J.L., Oelkers, E.H., Bienvenu, P., Colon, J., Donval, J.P., Fouquet, Y., Prieur, D., Appriou, P., 2002, The Rainbow vent fluids $\left(36^{\circ} 14^{\prime} \mathrm{N}, \mathrm{MAR}\right)$ : the influence of ultramafic rocks and phase separation on trace metal content, in Mid-Atlantic Ridge hydrothermal fluids: Chemical Geology, 184, 37-48.
Dymond, J., Corliss, J.B., Heath, G.R., Field, C.W., Dasch, E.J., Veeh, H.H., 1973, Origin of metalliferous sediments from the Pacific Ocean: Geological Society of America Bulletin, 84, 3355-3372.

Fustec, A., Desbruyéres D., Laubier, L.,1988, Estimation de la biomasse des peuplements associes aux sources hydrothermales profondes de la dorsale du Pacifique oriental á $13^{\circ} \mathrm{N}$, in Laubier, L. (ed.), Actes du Colloque «Les Sources Hydrothermales de la Ride du Pacifique Oriental, Biologie et Ecologie»: Institut Oceanographigue, Paris, November 4-7, Oceanologica Acta, Special, 8, 12-21.

Gal'chenko, V.F., Lein, A.Y, Miller, Y.M., Ivanov, M.V., 1989, Role of endosymbiotic bacteria in feeding of some invertebrates from the hydrothermal vent fields. In Lisitzin, A.P. (ed.), Geological setting and hydrothermal formations of the Juan-de-Fuca Ridge: Nauka, Moscow, Russia, 177-182 (in Russian).

Galkin, S.V., 2002, Hydrothermal vent communities of the World Ocean: structure, typology, and biogeography: Moscow, Russia, Nauka, 197 pp. (in Russian).

García-Hernández, J., King, K., Velasco, A.L., Shumilin, E., Mora, M.A, Glenn, E.P., 2001, Selenium, selected inorganic elements, and organochorine pesticidas in bottom material and biota from the Colorado River delta: Journal of Arid Environments, 49, 65-89.

Green-Ruiz, C., Ruelas-Inzunza, J., Páez-Osuna, F., 2005, Mercury in surface sediments and benthic organisms from Guaymas Bay, east coast of the Gulf of California: Environmental Geochemistry and Health, 27, 321-329.

Kádár, E., Costa, V., 2006, First report on the micro-essential metal concentrations in bivalve shells from deep-sea hydrothermal vents: Journal of Sea Research, 56, 37-44.

Kádár, E., Costa, V., Segonzac, M., 2007, Trophic influences of metal accumulation in natural pollution laboratories at deep-sea hydrothermal vents of the Mid-Atlantic Ridge: Science of the Total Environment, 373, 464-472

Klitgord, K.D., Mudie, J.D., Bischoff, J.L., Henyey, T.L., 1974, Magnetic anomalies in the northern and central Gulf of California: Geological Society of America Bulletin, 85, 815-820.

Lein, A.Y., Gal'chenko, V.F., Grinenko, V.A., Ulyanova, N.V., Voropaev, A.V., Guzhova, A.V., 1988, Mineralogy and geochemistry of rocks with bacterial overgrowth from the deep-sea hydrothermal mounds: Geokhimiya (Geochemistry), 9, 1235-1248 (in Russian).

Lein, A.Y., Sedykh, E.M., Starshinova, N.P., Miklishansky, A.Z., Galkin, S.V., Wulfson, E.K., 1989, Metals distribution in bacteria and animals of the deep-sea hydrothermal fields: Geokhimiya (Geochemistry), 2, 297-303 (in Russian).

Li, Y.H., 1991, Distribution patterns of the elements in the ocean: Geochimica et Cosmochimica Acta, 55, 3223-3240

Lonsdale, P.F., Bischoff, J.L., Burns, V.M., Kastner, M., Sweeney, R.E., 1980, A high-temperature hydrothermal deposit on the sea bed at Gulf of California spreading center: Earth and Planetary Sciences Letters, 49, 8-20. 
Lukashin, V.N., Galkin, S.V., Lein, A.Y., 1990, Features of chemical composition of the deep-sea hydrothermal animals: Geokhimiya (Geochemistry), 2, 279-285 (in Russian).

Méndez, L., Salas-Flores, L.M., Arreola-Lizarraga, A., Alvarez-Castañeda, S.T., Acosta, B., 2002, Heavy metals in clams from Guaymas Bay, Mexico: Bulletin of Environmental Contamination and Toxicology, 68, 217-223.

Méndez, L., Palacios, E., Acosta, B., Monsalvo-Spencer, P., AlvarezCastañeda, T., 2006, Heavy metals in clam Megapitaria squalida collected from wild and phosphorite mine-impacted sites in Baja California, Mexico. Considerations for human health effects: Biological Trace Element Research, 110, 275-307.

Millero, F., 1996, Chemical Oceanography, CRC Press: Boca Raton, Florida, $469 \mathrm{p}$.

Otero, X.L., Huerta-Diaz, M.A., Macías, F., 2003, Influence of a turbidite deposit on the extent of pyritization of iron, manganese and trace metals in sediments from the Guaymas Basin, Gulf of California (Mexico): Applied Geochemistry, 18, 1149-11.

Páez- Osuna, F., Osuna-López, J.I., Izaguirre-Fierro, N.G., Zazueta-Padilla, H.M., 1993, Heavy metals in clams from a subtropical coastal lagoon associated with an agricultural drainage basin: Bulletin of Environmental Contamination and Toxicology, 50, 915-921.

Roesijadi, G., Crecelius, E.A., 1984, Elemental composition of the hydrothermal vent clam Calyptogena magnifica from the East Pacific Rise: Marine Biology, 83, 2, 155-161.

Ruelas-Inzunza, J. R., Páez-Osuna, F., 2000, Comparative bioavailability of trace metals using three filter-feeder organisms in a subtropical coastal environment (Southeast Gulf of California): Environmental Pollution, 107, 437-444.

Ruelas-Inzunza, J., Soto, L.A., Páez-Osuna, F., 2003, Heavy metal accumulation in the hydrothermal vent clam Vesicomya gigas from Guaymas basin, Gulf of California: Deep Sea Research I, 50, 757-761.

Ruelas-Inzunza, J., Páez-Osuna, F., Soto, L.A., 2005, Bioaccumulation of $\mathrm{Cd}, \mathrm{Co}, \mathrm{Cr}, \mathrm{Cu}, \mathrm{Fe}, \mathrm{Hg}, \mathrm{Mn}, \mathrm{Ni}, \mathrm{Pb}$ and $\mathrm{Zn}$ in trophosome and vestimentum of the tube worm Riftia pachyptila from Guaymas basin, Gulf of California: Deep-Sea Research I, 52, 1319-1323.

Sarradin, P.M., Lannuzel, D., Waeles, M., Crassous, P., Le Bris, N., Caprais, J.C., Fouquet, Y., Fabri, M.C., Ricardo-Riso, R., 2008, Dissolved and particulate metals $(\mathrm{Fe}, \mathrm{Zn}, \mathrm{Cu}, \mathrm{Cd}, \mathrm{Pb})$ in two habitats from an active hydrothermal field on the EPR at $13^{\circ} \mathrm{N}$ : Science of the Total Environment, 392, 119-129.
Soto-Jiménez, M.F., Páez-Osuna, F., Scelfo, G., Hibdon, S., Franks, R., Aggarawl, J., Flegal, A.R., 2008, Lead pollution in subtropical ecosystems on the SE Gulf of California coast: A study of concentrations and isotopic composition: Marine Environmental Research, 66, 451-458.

Tambiev, S.B., Demina, L.L., 1992, Biogeochemistry and fluxes of manganese and some other metals in the regions of hydrothermal activity (Axial Mountain, Juan de Fuca Ridge and Guaymas Basin, Gulf of California): Deep-Sea Research, 39, 687-703.

Thunell, R.C., 1998, Seasonal and annual variability in particle fluxes in the Gulf of California: A response to climate forcing: Deep Sea Research Part I, 45, 2059-2083.

Tunnicliffe, V., 1991, The biology of hydrothermal vents:ecology and evolution: Oceanography and Marine Biology: An Annual Review, 29, 319-407

Van Dover, C.L., 2000, The Ecology of Deep-Sea Hydrothermal Vents. Prinston University Press: Princeton, New Jersey, 424 p.

Von Damm, K.L., 1990, Seafloor hydrothermal activity: Black smoker chemistry and chimneys: Annual Review of Earth and Planetary Sciences, 18, 173-204.

Von Damm, K.L., Edmond, J.M., Measures, C.I., Grant, B., 1985, Chemistry of submarine hydrothermal solutions at Guaymas Basin, Gulf of California: Geochimica et Cosmochimica Acta, 49, 2221-2237.

Von Damm, K.L., 2000, Chemistry of hydrothermal vent fluids from 9-10 N, East Pacific Rise: "Time zero", the immediate posteruptive period: Journal of Geophysical Research, 105, 11203-11222.

Manuscript received: July 27, 2008.

Corrected manuscript received: December 12, 2008.

Manuscript accepted: December 20, 2008. 